\title{
Review Article \\ Physical Activity and Hip Fracture Disability: A Review
}

\author{
Ray Marks ${ }^{1,2}$ \\ ${ }^{1}$ Department of Health and Behavior Studies, Teachers College, Columbia University, Box 114, 525W 120th Street, New York, \\ NY 10027, USA \\ ${ }^{2}$ Gerontological Studies and Services, Department of Health and Physical Education, York College, City University of New York, \\ New York, NY 10016-4309, USA
}

Correspondence should be addressed to Ray Marks,rm226@columbia.edu

Received 6 September 2010; Revised 11 November 2010; Accepted 28 January 2011

Academic Editor: Iris Reuter

Copyright ( 2011 Ray Marks. This is an open access article distributed under the Creative Commons Attribution License, which permits unrestricted use, distribution, and reproduction in any medium, provided the original work is properly cited.

Objective. The present paper examines pertinent literature sources published in the peer-reviewed English language between 1980 and November 1, 2010 concerning hip fractures. The aim was to highlight potential intervention points to offset the risk of incurring a hip fracture and its attendant disability. Methods. An in-depth search of the literature using the key terms: disability, epidemiology, hip fracture, prevention, and risk factors was conducted, along with data from the author's research base detailing the disability associated with selected hip fracture cases. All articles that dealt with these key topics were reviewed, and relevant data were tabulated and analyzed. Results. Hip fractures remain an important but potentially preventable public health problem. Among the many related remediable risk factors, low physical activity levels are especially important. Related determinants of suboptimal neuromuscular function also contribute significantly to hip fracture disability. Conclusion. Physical activity participation can help to reduce the prevalence and excess disability of hip fractures and should be encouraged.

\section{Background to the Problem}

In spite of much research, hip fractures continue to pose a serious health care problem as far as health policy makers and public health care organizations are concerned. Indeed, despite some evidence of declining hip fracture prevalence rates (e.g., $[1,2])$, hip fractures remain a persistent cause of excessive morbidity, reduced life quality, and premature mortality among older adults $[3,4]$. In addition, because the observed reversal of the hip fracture secular trend may not apply universally [5], it is likely the annual incidence of hip fractures will increase, rather than decrease over the next few decades [6].

Moreover, since hip fracture prevalence increases exponentially with age [7], as populations age and longevity increases worldwide [8], these injuries are likely to occur at accelerated rates [9]. This is important, because among those who sustain a hip fracture injury and survive, an increasing number continue to experience various degrees of subsequent disability, including the onset of painful disabling hip joint osteoarthritis, a high risk for falls, and further hip fracture injury. As a result, escalating and excessive monetary costs of care for this debilitating injury [8], which includes disability costs, nursing care, rehabilitation care, and surgical costs are predicted as well.

The aforementioned likelihood of an increase, rather than a universal decrease in hip fracture prevalence rates, along with their immense social, physical, and economic costs has recently endorsed the idea that continued vigilance plus the implementation of effective preventive strategies against hip fracture are essential $[3,8]$. However, what should be screened for, and what strategies for prevention should be implemented, is uncertain. Indeed, without a better understanding of why hip fractures occur, just how debilitating these injuries are, and how subsequent treatment of these injuries might be better targeted to reduce their complications and to restore optimal function to the affected individual, progress in this area is likely to be very limited.

To examine why hip fractures occur and what is needed to reduce their immense deleterious impact and improve long-term outcomes, this paper sought to examine what factors continue to account for the marked susceptibility of aging adults to hip fracture disability. The specific aim was to provide recommendations for preventing hip fractures 
and their complications based on this information. To this end, all relevant full-length published studies in the English language detailing the epidemiology and possible causes of hip fractures in the published data base over the time periods 1980-2010 were examined. Specific emphasis was placed on identifying changeable factors that heighten the risk for hip fracture and hip fracture disability. As well, an attempt was made to highlight the impact of this condition. Finally, a tentative framework for improving preventive directives against first and second hip fractures was developed based on the available evidence.

\section{Methods}

To achieve the goals of this paper, the relevant literature was sought through an in-depth environmental scan of all English language studies published in the PUBMED, Medline, and CINAHL data bases between 1980 and November, 2010 on the aforementioned topics. The key search terms used were disability, epidemiology, hip fracture, prevention, and risk factors. All related articles that reported on hip fracture surgical procedures or pathological fractures were excluded from this report. To achieve the goal of this paper, which was to obtain a comprehensive understanding of the magnitude and severity of hip fracture injuries, all 5 levels of evidence, categorized as ranging from I to $\mathrm{V}$, or from excellent to poor, as defined by the Oxford Centre for EvidenceBased Medicine in the United Kingdom, and used to denote the quality of a research study, were deemed acceptable. That is, the present paper examined all peer-reviewed research articles reporting pertinent topical data, regardless of design quality or methodology, and scrutinized these with respect to three themes, the scope of the problem or hip fracture epidemiology, the key risk factors for hip fracture and hip fracture disability, and the associated recommendations for preventing hip fracture disability.

In addition, to better understand the need to continue to examine and intervene upon changeable risk factors underpinning this debilitating condition, prospective data obtained as part of a larger study on hip fractures and knee muscle function were reviewed. Several related observations on hip fracture outcomes and potential explanatory factors for these were also reviewed and reported. No systematic review was attempted due to the vast range of issues and limited numbers of level I related studies, and no rehabilitation studies were analyzed directly.

\section{Results}

3.1. Epidemiological Trends and Scope of Problem. Despite declining hip fracture incidence rates in some locations [10-13], a vast body of diverse research since the 1980s has generally shown the age-adjusted incidence of hip fractures is increasing or likely to increase in the next few decades [14-25]. Also predicted to increase are related health care expenditures [8]. Hip fracture incidence rates are not static however, and may vary, as a result of seasonality, the relationship between the community and health care system and extent of comorbidities, among other factors [26].

Yet, regardless of variations in hip fracture incidence, there is general consensus that hip fractures remain a major cause of excess mortality and substantial disability $[25,27$, 28] and nursing home use [27] and this involves enormous medical and rehabilitation costs annually $[29,30]$. Further, given that most hip fracture patients are elderly, report more signs of diseases than controls [23], and suffer comorbidities [31] that pose a high risk for complications at high rates, the direct costs of a hip fracture could be at least threefold higher than those basic estimates previously mentioned [32]. Moreover, as well as the excess mortality from a hip fracture of between 10 and 20 percent $[33,34]$, of those who survive, half will have longstanding disability [35], shortterm hospital care stays of high duration $[36,37]$, and will generally occupy 20 to 25 percent of all orthopedic beds [36]. In addition, rehabilitation in this condition is slow [38], especially in the older patient [38], and of survivors, only two-thirds will return home [39], while 19 to 27 percent will require long-term institutional care [40].

Of further importance in the context of minimizing hip fracture disability is data showing hip fracture cases are commonly susceptible to multiple hip fractures. That is, a second hip fracture, which may be in the same location as the initial fracture with a tendency to greater displacement or instability is found to occur about six percent of the time and within a three- [14] to four-year postfracture period [41]. Further, Dolk [42] predicts the frequency of sustaining two hip fractures over the course of an individual's lifetime could reach 20 percent. In addition, because new hip fractures may occur on the same side as well on the opposite side to an initial fracture, it may be possible to sustain three hip fractures over time. According to Schroder et al. [43], the risk of incurring a third hip fracture per 1000 men is 8.6 and 9.8 per 1000 women, per year.

As a result of the magnitude and severity of a single hip fracture injury and its consequences, several studies have attempted to identify factors associated with a high risk of suffering both a first as well as a second hip fracture [4447]. In the author's own work, it has been apparent that hip fracture survivors may incur substantive years of disability and unwarranted debility (see Table 1), and this universal problem demands more be done to alleviate the widespread suffering and costs.

3.2. Risk Factors for Hip Fracture. Risk factors can generally be categorized as those that cannot be changed readily or are nonmodifiable and those that can potentially be changed or modified.

3.2.1. Nonmodifiable Factors. Chief nonchangeable factors that heighten susceptibility to hip fracture include age, gender, race or ethnicities, and geography.

Gender and Age. Among research concerning the relationship between hip fractures and age, evidence shows aging 
TABLE 1: Selected cases with a hip fracture history, their body mass indices, and their disability levels, showing only $25 \%$ of cases are underweight [48].

\begin{tabular}{|c|c|c|c|c|c|}
\hline Age & Gender & Fracture history & Functional status-2000 & $\begin{array}{l}\text { Body } \\
\text { mass } \\
\text { index }\end{array}$ & Subsequent surgical history \\
\hline$* * 67$ & $\mathrm{~F}$ & $\begin{array}{l}\text { Sustained Sept 1998, underwent } \\
\text { surgery, but hardware was } \\
\text { removed because of infection, } \\
\text { Oct } 1998 .\end{array}$ & $\begin{array}{l}\text { Nonambulatory for } 12 \text { months } \\
\text { and in severe pain. }\end{array}$ & 25 & $\begin{array}{l}\text { After various treatments in } 1999 \text { to } \\
\text { reduce infection, the total hip } \\
\text { arthroplasty previously inserted was } \\
\text { removed and reimplanted. }\end{array}$ \\
\hline$* * * 70$ & $\mathrm{~F}$ & $\begin{array}{l}\text { Sustained L hip fracture } 1990 \text {, } \\
\text { and developed avascular necrosis } \\
\text { requiring total hip replacement }\end{array}$ & $\begin{array}{l}\text { Ambulated min distance with } \\
\text { crutch or cane. }\end{array}$ & 25 & $\begin{array}{l}\text { Started to have pain in } 2000 \text {, which } \\
\text { progressed and was diagnosed as due to a } \\
\text { loose L total hip replacement that } \\
\text { required revision. }\end{array}$ \\
\hline 75 & F & $\begin{array}{l}\text { Initially sustained R hip fracture } \\
1995 .\end{array}$ & $<1$ block with cane. & 27 & $\begin{array}{l}\text { Failed hemiarthroplasty required revision } \\
\text { with total hip arthroplasty because } \\
\text { arthroplasty had worn down cartilage. } \\
\text { Hospitalized for } 14 \text { days, then sent to } \\
\text { rehabilitation center. }\end{array}$ \\
\hline 76 & $\mathrm{~F}$ & $\begin{array}{l}\text { Sustained fracture following fall } \\
\text { 1990, required surgery, but } \\
\text { developed problems requiring } \\
\text { revision after } 3 \text { months. }\end{array}$ & $\begin{array}{l}\text { Min distance with cane due to } \\
\text { pain. }\end{array}$ & 22 & $\begin{array}{l}\text { Total hip replacement had failed and } \\
\text { required revision. } \\
\text { After } 5 \text { days could walk a max distance of } \\
70 \text { foot with support and was discharged } \\
\text { to a Rehabilitation Center. }\end{array}$ \\
\hline $\begin{array}{l}* * * 77 \\
* * \\
*\end{array}$ & $\mathrm{~F}$ & $\begin{array}{l}\text { Sustained R hip fracture } 1983 \\
\text { followed by surgery, and R total } \\
\text { hip replacement in 1987, then } \\
\text { had L hip surgery in } 1999 \\
\text { following a fracture on L. }\end{array}$ & Unable to walk due to pain. & 29 & $\begin{array}{l}\text { L total hip replacement had failed and } \\
\text { required conversion to total hip } \\
\text { replacement. } \\
\text { After } 6 \text { days could walk approximately } 50 \\
\text { foot with rolling walker and supervision } \\
\text { and was discharged to a rehabilitation } \\
\text { center. }\end{array}$ \\
\hline$* 83$ & $\mathrm{~F}$ & $\begin{array}{l}\text { Initially sustained R femoral neck } \\
\text { hip fracture } 1999 .\end{array}$ & Wheel chair bound. & 27 & $\begin{array}{l}\text { Initially improved after surgical } \\
\text { reduction, then deteriorated to point } \\
\text { where she could not walk and required a } \\
\text { total hip arthroplasty. } \\
\text { After } 8 \text { day could walk } 25 \text { foot with } \\
\text { crutches and supervision and was } \\
\text { discharged home with physical therapy. }\end{array}$ \\
\hline $\begin{array}{l}* * * 85 \\
* * \\
*\end{array}$ & M & $\begin{array}{l}\text { Initially sustained a R hip fracture } \\
1999 \text { after a fall. }\end{array}$ & $\begin{array}{l}\text { Able to walk max of } 1 \text { block } \\
\text { with walker. }\end{array}$ & 30 & $\begin{array}{l}\text { Original hardware consisting of pinning } \\
\text { of the original fracture site required } \\
\text { removal and conversion to total hip } \\
\text { replacement due to pain. } \\
\text { Was hospitalized for } 8 \text { days then sent to } \\
\text { rehabilitation center. }\end{array}$ \\
\hline 90 & $\mathrm{~F}$ & $\begin{array}{l}\text { Sustained R hip fracture that was } \\
\text { pinned April 2000, but } \\
\text { experienced failure of pin } 2 \\
\text { months later and underwent } \\
\text { hemiarthroplasty. }\end{array}$ & Unable to walk. & 21 & $\begin{array}{l}\text { Diagnosed as having a malpositioned } \mathrm{R} \\
\text { hemiarthroplasty with a greater } \\
\text { trochanteric fracture requiring removal } \\
\text { and replacement with a new total hip } \\
\text { replacement. } \\
\text { After } 7 \text { days could walk a min distance } \\
\text { with a walker and was transferred to a } \\
\text { Skilled Nursing Facility for rehabilitation. }\end{array}$ \\
\hline
\end{tabular}

\footnotetext{
*Also has prior history of hip fracture on opposite side.

** Evidence of strength deficit of affected leg.

$* * *$ Diabetes.
}

adults, especially women, are more highly susceptible to hip fractures as they age compared to men [49-51]. Indeed, by age 90 , one in four women compared to one in eight men will probably sustain a hip fracture [39], despite an observed trend break for New Zealand women [52] and Swedish women [53]. In Korea, however, this trend differs and between 2001 and 2004 hip fracture rates for women increased 4.7 percent [54]. In addition, in China Shenyang Province and in Turkey, where men do heavy physical labor, the normal female/male hip fracture ratio was reversed $[17,55]$. 
Moreover, for very old women and men, the same risk of hip fracture exists in these countries [56], suggesting adults of both genders are highly susceptible to hip fractures as they age.

Ethnicity and Geographic Location. In terms of ethnicity, hip fracture rates are said to be greater among whites than among nonwhite populations [57-59] although this gap seems to be narrowing [60]. However, considerable variation within the nonwhite populations exists $[21,61]$. In addition, in recent years comparable rates of hip fracture among Kuwaiti females have been observed relative to some European countries and rates for males that were equal to those of white males in the United States [62], suggesting aging adults of all ethnicities may be susceptible to hip fractures.

In terms of geography, research conducted within the United States shows a north-to-south gradient in rates of both hip fracture types exists among women, while no clear pattern exists for men. Similarly, in central Norway, there is a lower incidence of hip fractures in subjects who live in rural areas compared to those that live in urban areas [63]. In Poland, however, where hip fracture rates are amongst the lowest in Europe, the incidence rate in the 50-65 year age group was 50 percent higher for women than men [64]. Thus, no predictable geographic pattern exists, so it remains difficult to envision precisely where one should focus primary prevention efforts.

Impaired Cognition. In addition to the aforementioned factors, another relatively unchangeable intrinsic factor that can heighten falls risk plus the advent of a hip fracture is the presence of irreversible cognitive impairments [65-74], which can slow central integration processes and heighten the potential for inappropriately delayed or weakened muscular responses [65]. As well, a prevailing cognitive impairment, along with a visual impairment [75] may impact the effectiveness of postoperative rehabilitation strategies [76], as well as functional recovery following a hip fracture [28], refracture rates [14]. It is thus crucially important in the context of preventing hip fractures to recognize and minimize cognitive declines that occur with age, such as depression [77], which increases the risk for hip fracture [78]. In this regard, recent research shows physical stimulation [79] and physical rehabilitation [80] can be quite useful.

\subsubsection{Modifiable Factors}

Bone Mineral Density. Since a hip fracture is the most devastating consequence of osteoporosis [78], bone mineral density is often the organ targeted in efforts to minimize hip fractures. Yet, while bone density measures at the femoral neck have been found to be strongly predictive of hip fractures in both men and women in some cases [81], other studies have found a considerable overlap in bone densities between hip fracture patients and age- and gender-matched controls after the age of 70, or no clear independent risk [8285]. In addition, Wei et al. [86] found the effect of risk factors for hip fracture among community-dwelling ambulatory elderly to remain the same, regardless of femoral neck bone mineral density. It has also been observed that bone mineral density is a weaker predictor of intertrochanteric hip fractures than femoral neck fractures [87], that osteoporotic indices were comparable between cases and controls [88], and that hip fracture patients were not more osteopenic than age and gender-matched controls [89]. Moreover, Asians, who have similar or lower bone mineral densities than whites and partake in diets low in calcium, have a low incidence rate of hip fracture, especially in women [17]. Mathematical models too cannot account for the exponential rise in hip fractures with age solely on the basis of bone density levels [90]. Further, individuals with osteoarthritis and higher bone density levels than the norm are not protected against hip fractures [91], and low bone density itself is not likely to cause most hip fracture injuries, given that falls seem to precede these. Such findings strongly suggest factors other than having a low bone mineral density and peak bone mass may contribute to the risk of fracturing a hip, including the extent of long-term physical loading [28]. Thus, even if preventable, an examination of factors unrelated to bone mass must merit consideration in establishing the causes of hip fractures.

These factors include those that increase the risk for falling, the mode of falling, the property of the fall surface, the degree of soft tissue covering the bone, the use of ambulatory aids, the prevailing degree of agility, motor function, and muscle weakness [56, 85, 92-98] (see Table 2). A further factor that may specifically lead to osteoporosis as well as to increases in the propensity to fall and fracture a hip is the adoption of consistently low levels of physical activity participation [98] although the effects of physical activity on bone mineral density and bone quality may not be sufficient to completely eliminate fracture risk [99].

Falls Risk. As observed more than a decade ago by Apple and Hayes [109], over 90 percent of hip fractures are associated with falls. As a result, understanding the risk factors for falls has become paramount in attempts to reduce hip fracture rates among older adults who are highly susceptible to falls. Among these fall-related mediators are intrinsic factors such as balance impairments [50, 104, 106, 110], neuromuscular and musculoskeletal impairments $[111,112]$, aberrant fallsrelated biomechanical responses [30, 113], visual deficits, muscle weakness [110], and depression [104]. In addition, cognitive impairments [104] and fear of falling [114], a serious disorder in older people, also increase the risk for falling and fracturing the hip [72]. Falls may also ensue as a result of age-associated declines in postural instability while turning [115], unanticipated interactions with environmental objects [116], perception, proprioception, transient circulatory insufficiencies [117, 118], impaired sensory integration or motor functioning [119], and/or "conservative movement performance" that reduces postural stability [119]. As such, preventing falls is highly challenging among the older population, and while highly desirable, falls are extremely difficult to predict and target uniformly. However, while most falls prevention programs thus pursue a multipronged intervention approach, a very strong and consistent 
TABLE 2: Selected findings spanning a 20-year period describing various intrinsic factors other than age and bone mass as potential hip fracture determinants and showing a high percentage implicate neuromuscular factors*. (Level evidence: I-V refers to study quality as outlined by the Oxford Centre for Evidence-Based Medicine.)

\begin{tabular}{|c|c|c|c|}
\hline Author and year & Type evidence & Level evidence & Hip fracture determinants \\
\hline Cummings and Nevitt, [90], 1989 & Expert opinion & $\mathrm{V}$ & Neuromuscular dysfunction* \\
\hline Cummings et al. [84], 1995 & Prospective study & II & Poor vision, weakness* \\
\hline Sihvonen et al. [100], 1994 & Theoretical model & $\mathrm{V}$ & Prior falls, low body mass \\
\hline Lauritzen [56], 1997 & Review & III & $\begin{array}{l}\text { Deficient soft tissue covering hip falls, } \\
\text { poor protective responses* }\end{array}$ \\
\hline \multirow[t]{2}{*}{ Slemenda et al. [93], 1997} & Review & III & Neuromuscular impairment* \\
\hline & & & Fall mechanics \\
\hline Dargent-Molina et al. [94], 1999 & Prospective study & II & Walking speed, poor mobility* \\
\hline \multirow[t]{3}{*}{ Fitzpatrick et al. [88], 2001} & Case control study & III & Factors related to falls* \\
\hline & & & Health perceptions \\
\hline & & & Low mental health score \\
\hline \multirow[t]{2}{*}{ Nguyen et al. [92], 2005} & Prospective study & II & Postural instability, muscle weakness* \\
\hline & & & Falls history, prior fracture \\
\hline Mussolino [78], 2005 & Prospective study & II & Depression \\
\hline $\begin{array}{l}\text { Rojanasthien and Luevitoonvechki } \\
\text { [101], } 2005\end{array}$ & Prospective study & II & Comorbidities, prior fracture \\
\hline Holmberg et al. [102], 2005 & Prospective study & II & Diabetes, poor self-rated health \\
\hline Wilson et al. [103], 2006 & Prospective study & II & $\begin{array}{l}\text { Poor physical function inability to lift } \\
10 \text { lbs* }^{*}\end{array}$ \\
\hline Has et al. [104], 2006 & Prospective study & II & Instability, muscle weakness* \\
\hline Abrahamsen et al. [105], 2007 & Case-control study & III & Prostate cancer and therapy \\
\hline Kulmala et al. [106], 2007 & Cross-sectional study & III & Balance confidence/function* \\
\hline Robbins et al. [107], 2007 & Observational study & III & $\begin{array}{l}\text { Poor health, prior fracture, smoking, } \\
\text { diabetes self-reported physical activity* }\end{array}$ \\
\hline Looker and Mussolino [108], 2008 & Cross sectional study & III & Vitamin D insufficiency \\
\hline Sihvonen et al. [100], 2009 & Cross sectional study & III & Postural instability* \\
\hline Lang et al. [96], 2010 & Cross sectional study & III & $\begin{array}{l}\text { Reduced amount of lean tissue of thigh } \\
\text { muscle* }\end{array}$ \\
\hline Jokinen et al. [98], 2010 & Prospective study & II & Low functional mobility* \\
\hline
\end{tabular}

determinant of most falls is clearly the degree of physical activity participation, as well as the type of activity, an aging adult adopts or neglects to adopt over time.

Physical Activity Participation. In terms of falls and hip fracture prevention approaches, a multitude of studies conducted over the past 30 years have consistently concluded that inactivity increases hip fracture risk among the elderly, while physical activity, which helps to maintain mobility, physical functioning, bone mineral density, joint flexibility, and muscle strength and balance can assist in preventing falls and fractures among the elderly [99]. Some of these studies are shown in Table 3 and all consistently imply low physical activity levels, must be considered a key determinant of hip fractures, regardless of whether the study is conducted using a case control or a prospective design, as outlined by Michaëlson et al. [120], Suriyawongpaisal et al. [121], Coupland et al. [122], Lyritis et al. [36], Wickham et al. [82], and others [123-125]. Indeed, Cooper et al. [83] found a low degree of physical activity participation doubled the risk of fracturing a hip, as did Kujala et al. [126] and Coupland et al. [122]. Importantly, these increases in risk remained even after adjusting for body mass index, smoking, alcohol consumption, and dependence in daily activities.

Interestingly, while simply increasing the hours of physical activity adults usually pursue per week can protect against the risk of hip fracture among community dwelling older adults [91], one of the reasons why low physical activity participation rates may heighten the risk for falling and fracturing a hip is due to its detrimental effect on vitamin D exposure [108], which in turn influences neuromuscular function adversely [92]. In addition, the lack of optimal load-bearing activities, which can influence bone quality quite detrimentally, may be the most salient explanatory factor for the increasingly high hip fracture rates reported by developing countries, as well as first-world countries [93], given our increasingly sedentary societies.

As well as increasing falls risk, a lack of adequate physical activity leading to poor muscle strength and endurance, coupled with aging, can hasten the onset and/or the progression 
TABLE 3: Over 20-years of research evidence showing degree of physical activity participation is a consistent predictor of hip fracture risk in the context of cross-sectional (Level III), case control (Level III), systematic reviews and prospective (Level II) studies as categorized according to Oxford Centre for Evidence-Based Medicine quality criteria.

\begin{tabular}{|c|c|c|}
\hline Authors and year & Study design & Finding \\
\hline $\begin{array}{l}\text { Lau et al. }[13], \\
1999\end{array}$ & $\begin{array}{l}\text { Case-control study of } 400 \text { Chinese men and women } \\
\text { with hip fractures and } 800 \text { controls. }\end{array}$ & $\begin{array}{l}\text { Daily walking outdoors, upstairs, uphill, or with a load } \\
\text { protected against sustaining a hip fracture, as did } \\
\text { higher levels of reported activity in middle life. }\end{array}$ \\
\hline $\begin{array}{l}\text { Cooper et al. } \\
{[83], 1988}\end{array}$ & $\begin{array}{l}\text { Case control study of } 300 \text { elderly men and women with } \\
\text { hip fracture and } 600 \text { controls matched for age and sex. }\end{array}$ & $\begin{array}{l}\text { Daily general and weight bearing activity protected } \\
\text { against sustaining a hip fracture. }\end{array}$ \\
\hline $\begin{array}{l}\text { Coupland et al. } \\
{[122], 1993}\end{array}$ & $\begin{array}{l}\text { Population based, case-control study of } 197 \text { patients } \\
\text { older than } 50 \text { years with hip fracture and } 382 \text { controls } \\
\text { matched by age and sex. }\end{array}$ & $\begin{array}{l}\text { Customary physical inactivity increased the risk for } \\
\text { sustaining a hip fracture in the elderly. }\end{array}$ \\
\hline $\begin{array}{l}\text { Grisso et al. } \\
{[123], 1997}\end{array}$ & $\begin{array}{l}\text { Case-control study of } 34 \text { hospitals and } 356 \text { men with } \\
\text { first hip fracture and } 402 \text { control men matched for age } \\
\text { and geographic location. }\end{array}$ & $\begin{array}{l}\text { Physical activity was markedly protective against } \\
\text { sustaining a hip fracture. }\end{array}$ \\
\hline $\begin{array}{l}\text { Kanis et al. [125], } \\
1999\end{array}$ & $\begin{array}{l}\text { Case-control study of } 730 \text { European men with hip } \\
\text { fracture and } 1132 \text { age-stratified controls followed } \\
\text { prospectively. }\end{array}$ & $\begin{array}{l}\text { Decreased physical activity and exposure to sunlight } \\
\text { accounted for the highest attributable risks for } \\
\text { sustaining a hip fracture among a number of different } \\
\text { risk factors. }\end{array}$ \\
\hline $\begin{array}{l}\text { Farahmand et al. } \\
{[127], 2000}\end{array}$ & $\begin{array}{l}\text { Population based case-control study of 1,327 women } \\
\text { with hip fracture and 3,262 randomly selected controls. }\end{array}$ & $\begin{array}{l}\text { There was a protective effect against sustaining a hip } \\
\text { fracture of recent leisure-associated physical activity. }\end{array}$ \\
\hline $\begin{array}{l}\text { Suriyawongpaisal } \\
\text { et al. [121], } 2001\end{array}$ & $\begin{array}{l}\text { Case-control study of } 187 \text { Thai men over } 51 \text { years of age } \\
\text { with hip fracture and } 177 \text { age-matched community } \\
\text { controls. }\end{array}$ & $\begin{array}{l}\text { Physical activity was independently associated with } \\
\text { reduced risk of sustaining a hip fracture after } \\
\text { controlling for confounding factors. }\end{array}$ \\
\hline $\begin{array}{l}\text { Englund et al. } \\
{[128], 2010}\end{array}$ & $\begin{array}{l}\text { Nested case-control study investigating associations } \\
\text { between bone markers, lifestyle, and osteoporotic } \\
\text { fractures that identified } 81 \text { female hip fracture cases } \\
\text { that had reported lifestyle data before they sustained } \\
\text { their fracture. Each case was compared with two female } \\
\text { controls identified from the same cohort and matched } \\
\text { for age. }\end{array}$ & $\begin{array}{l}\text { An active lifestyle in middle age seems to reduce the } \\
\text { risk of future hip fracture. }\end{array}$ \\
\hline $\begin{array}{l}\text { Wickham et al. } \\
{[82], 1989}\end{array}$ & $\begin{array}{l}15 \text {-year prospective study of 1,688 community dwelling } \\
\text { subjects. }\end{array}$ & $\begin{array}{l}\text { Physical activity participation protected against hip } \\
\text { fracture. }\end{array}$ \\
\hline $\begin{array}{l}\text { Gregg et al. [124], } \\
1998\end{array}$ & $\begin{array}{l}\text { Prospective study of } 9,704 \text { nonblack women } 65 \text { years of } \\
\text { age or older. }\end{array}$ & $\begin{array}{l}\text { Among older community-dwelling women, physical } \\
\text { activity is associated with a reduced risk for sustaining a } \\
\text { hip fracture. }\end{array}$ \\
\hline $\begin{array}{l}\text { Kujala et al. } \\
{[126], 2000}\end{array}$ & $\begin{array}{l}\text { Prospective study of } 3,262 \text { men, } 44 \text { years or older } \\
\text { followed for } 21 \text { years, or from age } 50 \text { for subjects } \\
\text { initially younger than } 50 \text { years. }\end{array}$ & $\begin{array}{l}\text { There is an inverse association between baseline } \\
\text { physical activity and future hip fracture risk among } \\
\text { men. }\end{array}$ \\
\hline \multirow{2}{*}{$\begin{array}{l}\text { Høidrup et al. } \\
{[129], 2001}\end{array}$} & \multirow{2}{*}{$\begin{array}{l}\text { Prospective study of leisure-time physical activity levels } \\
\text { and changes in relation to risk of hip fracture among } \\
1,211 \text { men and women with first hip fractures. }\end{array}$} & $\begin{array}{l}\text { Moderate levels of physical activity appear to protect } \\
\text { against later hip fracture. }\end{array}$ \\
\hline & & $\begin{array}{l}\text { Declining physical activity over time is an important } \\
\text { risk factor for hip fracture. }\end{array}$ \\
\hline $\begin{array}{l}\text { Devine et al. } \\
{[130], 2004}\end{array}$ & $\begin{array}{l}\text { A population based sample underwent bone mass } \\
\text { measures and answered surveys about their nutrition } \\
\text { and physical activity practices. }\end{array}$ & $\begin{array}{l}\text { A high level of physical activity and calcium } \\
\text { consumption was associated with a higher hip bone } \\
\text { mineral density. }\end{array}$ \\
\hline $\begin{array}{l}\text { Feskanich et al. } \\
{[131], 2002}\end{array}$ & $\begin{array}{l}\text { Prospective study to assess the relationship of walking, } \\
\text { leisure-time activity, and risk of hip fracture among } \\
51,200 \text { postmenopausal women. }\end{array}$ & $\begin{array}{l}\text { Moderate levels of activity, including walking, are } \\
\text { associated with substantially lower risk of hip fracture. }\end{array}$ \\
\hline $\begin{array}{l}\text { Morita et al. } \\
{[132], 2005}\end{array}$ & $\begin{array}{l}157 \text { women with hip fractures were followed between } \\
1989-1993 ; 216 \text { were followed between 199-2000. }\end{array}$ & $\begin{array}{l}\text { For prevention of hip fractures it is important to } \\
\text { improve physical function to void falls. }\end{array}$ \\
\hline $\begin{array}{l}\text { Michaelsson et al. } \\
{[120], 2007}\end{array}$ & Longitudinal, population-based study of 2,205 men. & $\begin{array}{l}\text { Regular sports activities can reduce the risk of hip } \\
\text { fractures in older men by one third. }\end{array}$ \\
\hline $\begin{array}{l}\text { Moayyeri [99], } \\
2008\end{array}$ & Meta-analysis of 13 prospective cohort studies. & $\begin{array}{l}\text { Moderate to vigorous physical activity is associated } \\
\text { with a hip fracture risk reduction of } 45 \% \text { and } 38 \% \\
\text { among men and women. }\end{array}$ \\
\hline
\end{tabular}


TABle 3: Continued.

\begin{tabular}{lll}
\hline Authors and year & Study design & Finding \\
\hline $\begin{array}{l}\text { Cawthon et al. } \\
{[133], 2008}\end{array}$ & $\begin{array}{l}\text { Prospective study of performance on 5 physical } \\
\text { function exams among 5902 men 65 years of age or } \\
\text { older. }\end{array}$ & $\begin{array}{l}\text { Poor physical performance was associated with an } \\
\text { increased risk of sustaining a hip fracture. }\end{array}$ \\
$\begin{array}{l}\text { Trimpou et al. } \\
{[134], 2010}\end{array}$ & $\begin{array}{l}\text { Prospective study of hip fractures in 7,496 men aged } \\
\text { 46-56 years. }\end{array}$ & $\begin{array}{l}\text { High degree of leisure-time physical activity, high } \\
\text { occupational class, and high BMI protected against } \\
\text { sustaining a hip fracture. However, work-related } \\
\text { physical activity was not protective. }\end{array}$ \\
\hline
\end{tabular}

of comorbid health conditions, another very important falls predictor. According to Hayes et al. [30], muscle weakness, which can reflect the degree and nature of physical activity participation especially increases the risk of fracturing a hip due to a fall because the intensity of the trauma may exceed the threshold to fracture more readily, regardless of bone strength. In addition, data suggest having weak muscles may also decrease the force required to fracture a hip [135] and a related decrease in the surrounding muscle mass [130] may imply a slower than normal reflex response and less protection of the underlying bone.

Low physical activity levels resulting in low levels of muscle strength also increases the chances of sustaining a hip fracture [83], because this can hasten bone demineralization [65], and diminish coverage of the underlying bone [72], thus impacting the magnitude of any prevailing fallrelated force on the hip joint $[131,136]$. Not surprisingly, an increased risk of falling, and possible hip fracture, has been specifically noted in association with neuromuscular impairments [93], declines in leg strength [110], low body and knee extensor strength [137], and the inability to rise from a chair without using one's arms [84]. In particular, the status of the neuromuscular systems at both the hip and knee, which is associated with physical activity participation, is shown to play a dominant role in determining hip fracture risk $[94,103]$.

The importance of being a physically fit adult across the lifespan is especially emphasized in the research presented by Parker and Palmer [138] and Myers et al. [139] who examined the relationships among prefracture status, the development of complications, and mobility outcomes at the time of discharge of the hip fracture patient. These researchers found prefracture status had a significant effect on these variables, particularly on ambulatory or mobility status [137]. As well as psychosocial factors [140], the ability to walk two weeks postoperatively [141], predicted return to the home environment, as did physical activity participation, and the ability to venture out and visit prior to the fracture.

Also, supporting the significance of prior physical activity participation in predicting posthip fracture outcomes is research by Fox et al. [142] who found that after adjusting for age, gender, race, and comorbidity, the patient's preexisting balance and summary mobility scores strongly predicted premature mortality. They also found poor balance, often linked to muscle weakness among other factors, frequently increased the need for hospitalization for up to 24 months post fracture. Further, cases with both poor balance and poor gait had increased odds of being placed in a nursing home or experiencing subsequent mobility problems and reduced independence.

Body Mass. In another series of studies, hip fracture risk has been deemed to be a product of the positive association between low body mass and fracture risk, especially among white men [143], after the age of 50 [144]. Yet, being underweight alone does not commonly lead to the development of a nonpathological hip fracture, suggesting other factors are involved [85]. Indeed, a hip fracture is much more likely to be attributed to the interaction of low body mass, low muscle mass, and muscle weakness leading to failure of protective responses, regardless of femoral bone density [35].

In addition, although most people who fracture their hips could be classified as being thin, Cumming and Klineberg [97] and Maffulli et al. [145] reported their patients with hip fractures tended to be overweight. Dretakis and Christadoulou [146] too noted similar rates of overweight and underweight hip fracture cases among their 373 patients. Similarly, when patients with severe dementia were excluded, Bean et al. [135] found thinness was not necessarily associated with hip fracture. However, their observations of differences in handgrip strength among hip fracture patients and controls of comparable body mass indices, suggested body mass in hip fracture cases might be constituted by a higher proportion of fat than muscle.

Thus, heavier individuals may not be immune to sustaining hip fracture injuries, despite their relatively higher proportion of body fat that can perhaps help dissipate a fall. This is because they may have restricted general mobility, their muscles may be constituted by a large fat mass, and the direct impact sustained by their high body weights may readily exceed the safety threshold of the underlying bone. These individuals are also be expected to have low levels of sex hormone-binding globulin, a finding among women with recent hip fractures [147], plus a high rate of comorbid conditions that are known risk factors for falling, such as hypertension, arthritis, diabetes and medical conditions associated with osteoporosis, such as cancer [105]. In this regard, much has been written about the significant impact of inactivity on rising obesity rates, and related conditions.

Chronic Illnesses. In addition to all the factors already mentioned, it is increasingly clear certain chronic illnesses, in particular, those that impair physical activity, such as arthritis and Parkinson's disease, substantially increase the risk 
of falling, and hence of incurring a hip fracture [66, 67, 148]. As well, comorbid factors that impair physical activity participation such as arrhythmias, postural hypertension, pain, and peripheral neuropathies may increase the risk of falls and hip fractures [35], as may the presence of lower limb dysfunction, Alzeimer's type dementia [149] and other neurological conditions, such as stroke [150]. Diabetes mellitus [151], hyperthyroidism, which is linked to obesity [152], plus medical conditions associated with osteoporosis [153], as well as other forms of disability associated with an increased risk of falling [153, 154], the use of walking aids [154], and those that require prolonged immobilization [42] may similarly heighten the risk of a hip fracture. Rehospitalization after hip fracture may also be influenced negatively by comorbid clinical problems [155], which limit function [156], and the increased use of at least one psychotropic drug, can lead to a second hip fracture [157]. Since the numbers of comorbid diseases continue to rise among aging populations, along with increasingly poor levels of physical functioning, it can be anticipated that the prevalence of hip fractures will continue to rise. Another factor implicated in hip fractures along with poor health status and physical activity limitations [71], is impaired vision [72-76], which may be amenable to intervention.

Environmental Circumstances. Environment refers to all those factors extrinsic to the individual such as home environment, outdoor environment, and work environment that may pose a hip fracture risk to a susceptible individual. Although not always a changeable factor, certain environmental risk factors for hip fractures may be amenable to modification. However, as shown by Norton et al. [158] who investigated the circumstances of falls resulting in hip fractures among older adults in New Zealand prospectively, of the 85 percent of fractures involving a fall that occurred at home, only about 25 percent of these were associated with an environmental hazard. This finding led the authors to conclude that regardless of age or residential status, intrinsic factors such as balance, play a greater role than extrinsic factors, in causing falls that cause hip fractures. Further, while environmental factors may be one of several factors that contribute to falls [159], a recent study by Allander et al. [160], which found the correlation between the number of risk factors of the faller and the environment to be 0.07 , suggested environmental hazards are of minimal importance in mediating hip fractures.

Parker et al. [116] who examined environmental hazards implicated in the aetiology of a consecutive series of 787 hipfracture patients, found 51 different hazards were implicated in the falls experienced by $58 \%$ of patients. The author's conclusion was that given the nature of these environmental hazards, measures to reduce the risk of falls due to environmental factors are unlikely to lead to a significant reduction in the incidence of hip fractures.

In summary, as indicated in the prevailing data base, a variety of age-related physiological changes and other factors including medication status may mediate two crucial determinants of hip fracture, namely, femoral bone strength and the propensity to trauma. In particular, the anticipated decline in muscle function with aging and/or comorbid health conditions is likely to impact both of these key injury determinants, and hence the incidence of hip fractures [50]. Moreover, muscle strength and size and its influence on mobility, reaction time, balance, proprioception, fracture site coverage, and bone mass may explain or contribute towards subgroup variations in hip fracture incidence, presentation, and functional outcomes (see Table 3 ). The nature of the hypothesized relationship between these factors and the disability associated with hip fractures is elaborated upon in graphic form in Figure 1. The detrimental impact of hip fractures on well-being is emphasized in Tables 1 and 4, where some additional predictors of hip fracture disability are shown.

\section{Preventing Hip Fractures and Hip Fracture Disability}

Over 20 years ago, Cummings and Klineberg [97] advocated for a better understanding of the physical factors that underlie hip fractures, a generally increasingly prevalent disabling injury among older populations worldwide $[170,171]$. In particular, they argued for the importance of the status of the neuromuscular system in mediating hip fractures. In this author's view, while many factors may be involved in the pathogenesis of hip fractures, physical activity defined as "any bodily movement produced by skeletal muscles that results in energy expenditure" [172] is key to reducing the risk of falls and premature bone loss that lead to hip fracture. As such, it is increasingly apparent that efforts to promote physical activity across the lifespan, in addition to the identification and remediation of adults with deficient muscle function and bone mass is likely to be of paramount importance in continuing efforts to effectively reduce hip fractures incidence rates and hip fracture disability. This stated importance of having adults pursue adequate levels of physical activity participation across the lifespan seems reasonable owing to the role played by muscle in influencing: (1) bone structure, (2) balance capacity, (3) the effectiveness of protective reflexes, (4) the ability to attenuate impact at the hip joint, (5) general mobility, (6) proclivity to falls and falling mechanisms. That is, concerted efforts to offer comprehensive screening opportunities that can examine lifestyle factors, along with the presence of muscle-related deficits among vulnerable adults as they age, including muscle strength and responsiveness, proprioception, joint range of motion, and balance capacity are likely to improve most modifiable hip fracture risk factors or prevent these, including excess comorbidity, obesity, poor muscle strength, and balance capacity. To achieve this, individually tailored programs that are based on a comprehensive health assessment and thereafter encourage appropriate levels of physical activity or exercise, especially weight-bearing activities, are highly recommended (see Table 5 and Figure 2).

In addition, ensuring individuals in developing as well as developed countries have the resources and/or knowledge or skill to partake in physical activities and are able to do 
TABLE 4: Studies over last 10 years describing poor outcomes after hip fracture, regardless of contemporary management and rehabilitation strategies, plus some common factors explaining outcomes.

\begin{tabular}{|c|c|c|c|}
\hline $\begin{array}{l}\text { Authors and } \\
\text { year }\end{array}$ & Hip fracture population & $\begin{array}{l}\text { Key findings concerning mortality } \\
\text { and morbidity }\end{array}$ & Factors explaining outcome \\
\hline $\begin{array}{l}\text { Giaquinto et al. } \\
{[161], 2000}\end{array}$ & 58 cases, mean age 86.7 years. & $\begin{array}{l}12 \text { patients died after complications } \\
\text { of previous risk factors, on average } \\
\text { survivors showed functional gains } \\
\text { from admission to discharge, but } \\
\text { most required supervision at } \\
\text { discharge. }\end{array}$ & $\begin{array}{l}\text { Age, type fracture, physical and } \\
\text { mental health status, and fear. }\end{array}$ \\
\hline $\begin{array}{l}\text { Maggio et al. } \\
{[162], 2001}\end{array}$ & 42 cases. & $\begin{array}{l}\text { The percentage of residents } \\
\text { ambulating autonomously fell from } \\
95-32 \text { percent among those with } \\
\text { fractures even though their } \\
\text { prefracture mobility status was } \\
\text { better than those who never } \\
\text { fractured their hips. }\end{array}$ & $\begin{array}{l}\text { Level of prefracture mobility or } \\
\text { preserved autonomous mobility. }\end{array}$ \\
\hline
\end{tabular}
fractured their hips.

Davidson et al. $\quad 331$ cases.
[33], 2001

Davidson et al. $\quad 331$ cases.
[33], 2001

Van Balen et al. Prospective study of 102 elderly hip [163], 2001 fracture patients mean age 83 years.

Kirke et al. [164], 2002

Undertook a 2 year follow up of 106 older Irish women with hip fracture histories and 89 without hip fracture.
Twelve-month mortality was 26 percent. Followup of 231 surviving patients 12-24 months later showed 27 percent still had pain and 60 percent had worsened mobility.

Mortality at 4 months was 20 percent. While 57 percent went back to original accommodations, 43 percent reached same level of walking ability, and 17 percent achieved same prefracture abilities of daily living, quality of life at 4 months was worse than the reference population.

Mortality at 1 year was 16 percent, and 23.6 percent at 2 years. This occurred even though males or subjects with moderate or severe mental impairment were not included in the study. Hip fracture also had a marked negative effect on functional independence.
Low Vitamin D levels, type of fracture and surgical repair.
Within approximately 4 years, 338 women had a first hip fracture, and their postfracture mortality rate was 112.4 per 1,000 woman-years, compared with 27.3 per 1,000 woman-years for the 6,115 women who did not have any fracture $(P<.001)$. After adjusting for age and baseline health status, women with hip fractures were more than twice as likely to die than women with no fractures.

with no fractures.

Mortality was 9.6 percent at 30 days, and 33 percent at one year.

The mortality rates at 6 and 12 months have remained essentially unchanged over the last 4 decades, and are approximately 11-23 percent at 6 months, and 22-29 percent at 1 year.
Poor mobility, multiple falls, and use of health and community services.
Local complications, wound infection, age, number of comorbidities, cognitive state at one week after surgery.
Empana et a
[166], 2004

Roche et al.

[156], 2005

Haleem et al. [3], 2008
Reviewed all articles on outcome of hip fracture between 1,959 and 1,998 .
Level of prefracture mobility. 
Table 4: Continued.

\begin{tabular}{llll}
\hline $\begin{array}{l}\text { Authors and } \\
\text { year }\end{array}$ & Hip fracture population & $\begin{array}{l}\text { Key findings concerning mortality } \\
\text { and morbidity }\end{array}$ & Factors explaining outcome \\
\hline $\begin{array}{l}\text { Haentjens et al. } \\
{[167], 2010}\end{array}$ & $\begin{array}{l}\text { Prospective studies from } 1957-2009 \\
\text { were examined, 22 women and 17 } \\
\text { men. }\end{array}$ & $\begin{array}{l}\text { Older adults have a 5-8 fold } \\
\text { increased risk for all-cause } \\
\text { mortality during the first 3 months } \\
\text { after hip fracture. Excess annual } \\
\text { mortality persists over time for both } \\
\text { women and men. }\end{array}$ & $\begin{array}{l}\text { Postoperative events, multiple } \\
\text { comorbid conditions. }\end{array}$ \\
\hline $\begin{array}{l}\text { Juliebø et al. } \\
{[168], 2010}\end{array}$ & $\begin{array}{l}\text { Prospective observational study of } \\
\text { 21 months duration, of 364 }\end{array}$ & $\begin{array}{l}\text { Six risk factors were identified for } \\
\text { predicting mortality after hip } \\
\text { fracture. }\end{array}$ & $\begin{array}{l}\text { History of cardiovascular disease, } \\
\text { male gender, low Barthel Index, low } \\
\text { body mass, and use of diuretics. }\end{array}$ \\
\hline $\begin{array}{l}\text { Ho et al. [169], } \\
2010\end{array}$ & $\begin{array}{l}\text { Retrospective study of prognostic } \\
\text { factors for survival at one year over } \\
\text { a 9-year period. }\end{array}$ & Overall survival rate was $86 \%$. & $\begin{array}{l}\text { Survival was lower in presence of } \\
\text { comorbidities, those of higher ages, } \\
\text { those with arthroplasties, and } \\
\text { delayed surgeries. }\end{array}$ \\
\hline
\end{tabular}

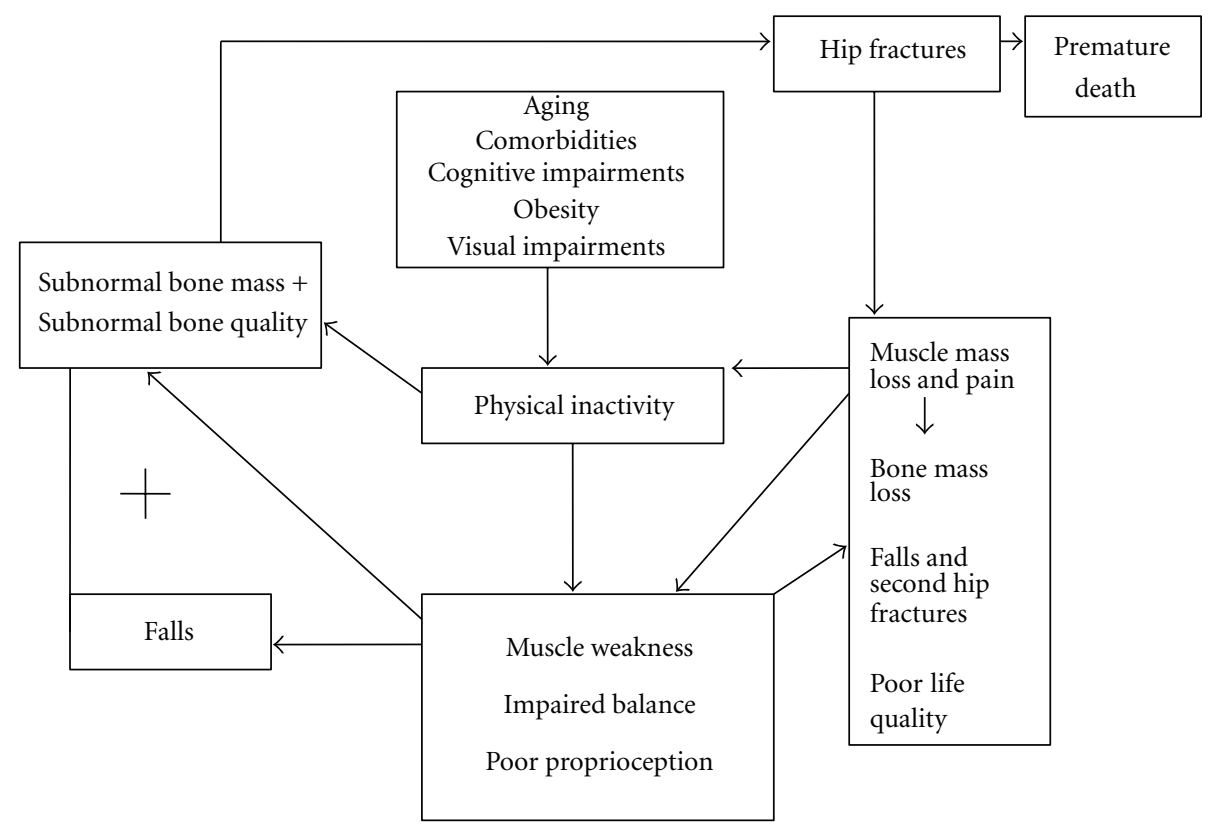

FIGURE 1: Model of key factors implicated in hip fracture injury.

so may foster the ability to maintain a healthy bone mass and optimal body weight across the lifespan as is indicated to offset unwarranted hip fracture disability. In this respect, adults with excessively low or high body weights, health conditions such as cancer or diabetes, cognitive or visual impairments, and those using steroids, benzodiazepines or other psychotropic agents should also be specifically targeted.

Other strategies that cannot be overlooked are the role of integrated bone and fall-related risk-factor assessment [158], the careful use of bone building supplements especially for hip fracture cases exhibiting difficulty performing effective physical exercise because of reduced walking ability [132], the reduction of remediable visual impairments and depression, and the avoidance of steroids, excessive smoking, caffeine and alcohol usage $[84,100]$. Factors that may be especially useful to examine regularly during annual check-ups are listed in Table 5. Other areas warranting attention in future studies include the potential predictors outlined by Wilson et al. [103] such as health insurance status, educational level, and type of residence. In addition to multidisciplinary prevention programs for osteoporosis and falls, plus better in and after care for hip fracture cases as indicated by Alvarez-Nebreda et al. [26], more education about hip fractures and their serious health outcomes is needed. To avoid excessive functional deterioration among hip fracture survivors, including further bone and muscle mass loss, a fat gain of 11 percent [174], plus a high risk for postoperative failures or secondary fractures, the need for rigorous postoperative diagnostic evaluations and treatment of comorbid conditions, especially in the male hip fracture patient, has been emphasized [175]. In addition, comprehensive and protracted rehabilitation interventions including pain control [173], bone-enhancing physical and/or pharmacologic interventions, sunlight exposure, and carefully 
TABLE 5: Representative commonplace assessments and related checklist that could be used in primary care or community settings during regular examinations as well as among those receiving surgical interventions for a first hip fracture to identify those at high risk for first and secondary hip fractures and poor outcomes, as well as associated potential intervention areas.

\begin{tabular}{|c|c|c|c|}
\hline Measures & & Results & \\
\hline \multicolumn{4}{|l|}{ Physical } \\
\hline Body weight & Underweight & Normal & Overweight \\
\hline Bone density status, bone scan, and ultrasound [94] & Normal & & Low \\
\hline Cardiac status and cardiogram & Normal & & Subnormal \\
\hline Blood pressure & Normal & High & Low \\
\hline Pain (visual analogue scale) [173] & & 012345678910 & \\
\hline Physical activity (yale physical activity survey) [173] & Normal & & Sedentary \\
\hline Smoker & yes & & no \\
\hline \multicolumn{4}{|l|}{ Musculoskeletal } \\
\hline Arm muscle circumference and triceps skinfold thickness [85] & Normal & & Subnormal \\
\hline Balance capacity, single-leg stance test, and berg balance scale [106] & Normal & & Subnormal \\
\hline Functional independence measure (FIM) [94] & Normal & & Subnormal \\
\hline Muscular strength and manual knee extensor muscle test & Normal & & Subnormal \\
\hline Sensorimotor reflexes, sensation, joint position sense & Normal & & Subnormal \\
\hline \multicolumn{4}{|l|}{ Clinical } \\
\hline Mental health status—Folstein minimental state exam & Normal & & Subnormal \\
\hline Drug usage—medication check list & $0-3$ & $4-6$ & $7+$ \\
\hline Fear of falling—survey & yes & & no \\
\hline Nutritional status—dietician & Normal & & Subnormal \\
\hline Medical conditions_-check list-physician & 0 & $1-3$ & $3+$ \\
\hline Previous falls history—survey & yes & & no \\
\hline Visual status & Normal & & Impaired \\
\hline \multicolumn{4}{|l|}{ Environmental } \\
\hline \multirow[t]{2}{*}{ Home hazards, visiting nurse, or occupational therapist } & yes & & no \\
\hline & \multicolumn{3}{|c|}{ List number of risk factors: _-__- } \\
\hline
\end{tabular}

designed physical activities are strongly indicated and need to be investigated in rigorous trials.

\section{Conclusions}

In 1987, Melton and Cummings [176] stated that in spite of a general impression to the contrary, the risk factors for age-related fractures were poorly understood. Almost 25 years later, while the key risk factors have been quite well studied, with few exceptions, it is difficult to pinpoint precisely what should be targeted in preventive efforts against hip fractures, as well as where this should take place, because the incidence rates for hip fracture vary widely [101]. In addition, while falls-related trauma and suboptimal bone strength appear to be key factors influencing hip fracture occurrences [177], neither factor alone sufficiently explains the exponential increase in hip fracture incidence rates that occur with aging [90]. However, as was reviewed more than ten years ago by Joakimsen et al. [178], it seems clear the extent of lifelong physical activity participation is especially important. This may be because physical activity participation potentially determines health status, plus the propensity to falling and fracturing a hip owing to its effect on neuromuscular as well as bone physiology. Cummings and Nevitt, 1989 [90] proposed that four conditions must be satisfied in order for a fall to cause a hip fracture: (a) the faller must be oriented to impact near the hip, (b) protective responses must fail, (c) local soft tissues must absorb less energy than necessary to prevent fracture, and (d) the residual energy of the fall applied to the proximal femur must exceed its strength. All of these events become more likely with aging and low physical activity levels and might explain the presently observed exponential rise in the risk of hip fracture with advancing age, despite bone building medication availability. Thus, a combination of targeted physical activities along with appropriate calcium intake, minimizing caffeine intake, maintaining a normal body weight, and avoiding long-term psychoactive medications and other interventions that prevent falls as outlined by Gillespie et al. [179] may prove to extremely efficacious for reducing the risk of hip fracture as outlined by Cummings et al. in 1995 [84]. 


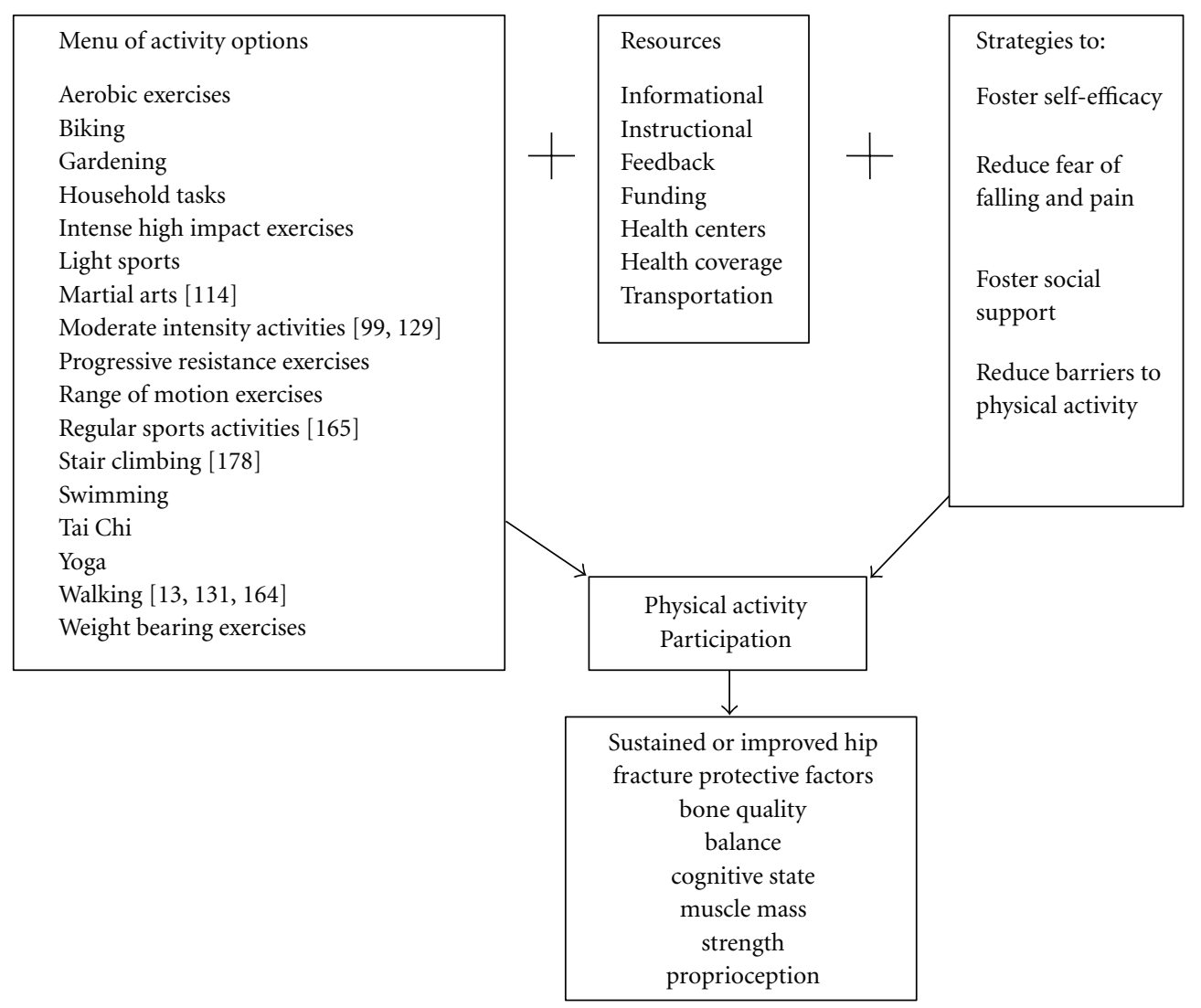

FIGURE 2: Selected modifiable factors that might facilitate physical activity participation among adults across the lifespan.

However, to offset the high mortality as well as high morbidity rates associated with hip fracture, this approach is more likely to succeed if implemented early on in adult life, rather than later on, when physical activity levels are likely to be quite low [91]. As well, since the propensity to fall, an important factor in the pathogenesis of hip fracture [180] may be related to excess alcohol consumption, medical comorbidities and visual problems [84], as well as physical fitness correlates, these at risk individuals should be targeted early on as well. Since muscle function and structure and its influence on bone quality and integrity can undoubtedly influence the impact of trauma on the structural properties of the hip joint, regardless of age, physical activity participation is key to preventing a fair majority of hip fractures due to slips, trips and falls, as well as osteoporosis, excessive depression, and a host of other chronic diseases that increase hip fracture risk, such as diabetes and cancer [132]. Cognitive status is usually affected favourably as well by physical activity participation, as is blood pressure, both health issues that heighten hip fracture risk as reported in the literature. Outdoor activities such as walking that expose older people to sunlight and vitamin D and enable them to weight bear in variable contexts may yield the benefits of both improving muscular function as well as bone structure.

To further prevent hip fracture disability and enhance hip fracture surgical outcomes, high-intensity strengthening and balance related exercises, plus activities that promote early weight bearing after surgery, and prolonged followup strategies are strongly indicated. To specifically reduce hip fracture morbidity and mortality rates associated with second hip fracture, those with comorbid conditions, cognitive disorders, visual impairments, and osteoporosis and those using psychotropic drugs should be strategically targeted.

As stated by Devine et al. [130], if the whole population followed a high physical activity lifestyle with adequate calcium consumption, it is likely the population risk of hip fractures could be reduced significantly. However, even though isolated high activity in later life provided similar protection to that of high physical activity participation in early adulthood [127] or by regular sports participation [134], rather than applying this approach belatedly to the older population, to achieve maximum protection, young adults everywhere need to be apprised of their future risk for hip fracture in later life and encouraged to be follow healthy active lifestyles.

\section{Acknowledgments}

The author thanks The Arthritis Foundation, New York Chapter, and The Cornell Aging Center, New York, who provided financial support for a substantial portion of this paper. 


\section{References}

[1] S. B. Jaglal, I. Weller, M. Mamdani et al., "Population trends in BMD testing, treatment, and hip and wrist fracture rates: are the hip fracture projections wrong?" Journal of Bone and Mineral Research, vol. 20, no. 6, pp. 898-905, 2005.

[2] J. A. Stevens and R. A. Rudd, "Declining hip fracture rates in the United States," Age and Ageing, vol. 39, no. 4, pp. 500-503, 2010.

[3] S. Haleem, L. Lutchman, R. Mayahi, J. E. Grice, and M. J. Parker, "Mortality following hip fracture: trends and geographical variations over the last 40 years," Injury, vol. 39, no. 10, pp. 1157-1163, 2008.

[4] S. E. Hall, J. A. Williams, J. A. Senior, P. R. T. Goldswain, and R. A. Criddle, "Hip fracture outcomes: quality of life and functional status in older adults living in the community," Australian and New Zealand Journal of Medicine, vol. 30, no. 3, pp. 327-332, 2000.

[5] E. Guilley, T. Chevalley, F. Herrmann et al., "Reversal of the hip fracture secular trend is related to a decrease in the incidence in institution-dwelling elderly women," Osteoporosis International, vol. 19, no. 12, pp. 1741-1747, 2008.

[6] L. E. Wehren and J. Magaziner, "Hip fracture: risk factors and outcomes," Current Osteoporosis Reports, vol. 1, no. 2, pp. 78 $85,2003$.

[7] E. J. Samelson, Y. Zhang, D. P. Kiel, M. T. Hannan, and D. T. Felson, "Effect of birth cohort on risk of hip fracture: agespecific incidence rates in the Framingham Study," American Journal of Public Health, vol. 92, no. 5, pp. 858-862, 2002.

[8] R. T. Wilson and R. B. Wallace, "Trends in hip fracture incidence in young and older adults," American Journal of Public Health, vol. 97, no. 10, pp. 1734-1735, 2007.

[9] R. Marks, "Hip fracture epidemiological trends, outcomes, and risk factors, 1970-2009," International Journal of General Medicine, vol. 3, pp. 1-17, 2010.

[10] L. J. Melton, A. E. Kearns, E. J. Atkinson et al., "Secular trends in hip fracture incidence and recurrence," Osteoporosis International, vol. 20, no. 5, pp. 687-694, 2009.

[11] T. Chevalley, E. Guilley, F. R. Herrmann, P. Hoffmeyer, C. H. Rapin, and R. Rizzoli, "Incidence of hip fracture over a 10year period (1991-2000): reversal of a secular trend," Bone, vol. 40, no. 5, pp. 1284-1289, 2007.

[12] T. M. Huusko, P. Karppi, V. Avikainen, H. Kautiainen, and R. Sulkava, "The changing picture of hip fractures: dramatic change in age distribution and no change in age-adjusted incidence within 10 years in Central Finland," Bone, vol. 24, no. 3, pp. 257-259, 1999.

[13] E. M. C. Lau, C. Cooper, H. Fung, D. Lam, and K. K. Tsang, "Hip fracture in Hong Kong over the last decade-a comparison with the UK," Journal of Public Health Medicine, vol. 21, no. 3, pp. 249-250, 1999.

[14] S. Mitani, M. Shimizu, M. Abo, H. Hagino, and Y. Kurozawa, "Risk factors for second hip fractures among elderly patients," Journal of Orthopaedic Science, vol. 15, no. 2, pp. 192-197, 2010.

[15] A. R. Lyons, D. B. Karpf, P. Lips, and C. Cooper, "Clinical outcomes and treatment of hip fractures," American Journal of Medicine, vol. 103, no. A, pp. 51S-64S, 1997.

[16] E. Lönnroos, H. Kautiainen, P. Karppi et al., "Increased incidence of hip fractures. A population based-study in Finland," Bone, vol. 39, no. 3, pp. 623-627, 2006.
[17] L. Yan, B. Zhou, A. Prentice, X. Wang, and M. H. N. Golden, "Epidemiological study of hip fracture in Shenyang, People's Republic of China," Bone, vol. 24, no. 2, pp. 151-155, 1999.

[18] L. Xu, A. Lu, X. Zhao, X. Chen, and S. R. Cummings, "Very low rates of hip fracture in Beijing, People's Republic of China: the Beijing osteoporosis project," American Journal of Epidemiology, vol. 144, no. 9, pp. 901-907, 1996.

[19] P. Kannus, J. Parkkari, H. Sievänen, A. Heinonen, I. Vuori, and M. Järvinen, "Epidemiology of hip fractures," Bone, vol. 18, no. 1, pp. 57S-63S, 1996.

[20] P. Kannus, S. Niemi, J. Parkkari, M. Palvanen, I. Vuori, and M. Järvinen, "Hip fractures in Finland between 1970 and 1997 and predictions for the future," The Lancet, vol. 353, no. 9155 , pp. 802-805, 1999.

[21] F. T. J. Boereboom, J. A. Raymakers, R. R. M. De Groot, and S. A. Duursma, "Epidemiology of hip fractures in The Netherlands: women compared with men," Osteoporosis International, vol. 2, no. 6, pp. 279-284, 1992.

[22] S.-R. Kim, Y.-C. Ha, J.-R. Kim, R. Kim, S.-Y. Kim, and K.-H. Koo, "Incidence of hip fractures in Jeju Island, South Korea: a prospective study (2002-2006)," Clinics in Orthopedic Surgery, vol. 2, no. 2, pp. 65-68, 2010.

[23] G. B. Jarnlo, "Hip fracture patients. Background factors and function," Scandinavian Journal of Rehabilitation Medicine, Supplement, supplement 24, pp. 1-31, 1991.

[24] P. Clark, P. Lavielle, F. Franco-Marina et al., "Incidence rates and life-time risk of hip fractures in Mexicans over 50 years of age: a population-based study," Osteoporosis International, vol. 16, no. 12, pp. 2025-2030, 2005.

[25] C. Cooper, G. Campion, and L. J. Melton, "Hip fractures in the elderly: a world-wide projection," Osteoporosis International, vol. 2, no. 6, pp. 285-289, 1992.

[26] M. L. Alvarez-Nebreda, A. B. Jiménez, P. Rodríguez, and J. A. Serra, "Epidemiology of hip fracture in the elderly in Spain," Bone, vol. 42, no. 2, pp. 278-285, 2008.

[27] C. L. Leibson, A. N. A. Tosteson, S. E. Gabriel, J. E. Ransom, and L. J. Melton, "Mortality, disability, and nursing home use for persons with and without hip fracture: a populationbased study," Journal of the American Geriatrics Society, vol. 50, no. 10, pp. 1644-1650, 2002.

[28] J. A. Kettunen, O. Impivaara, U. M. Kujala et al., "Hip fractures and femoral bone mineral density in male former elite athletes," Bone, vol. 46, no. 2, pp. 330-335, 2010.

[29] C. M. Koeck, D. L. B. Schwappach, F. M. Niemann, T. J. Strassmann, H. Ebner, and K. Klaushofer, "Incidence and costs of osteoporosis-associated hip fractures in Austria," Wiener Klinische Wochenschrift, vol. 113, no. 10, pp. 371-377, 2001.

[30] W. C. Hayes, E. R. Myers, S. N. Robinovitch, A. Van Den Kroonenberg, A. C. Courtney, and T. A. McMahon, "Etiology and prevention of age-related hip fractures," Bone, vol. 18, no. 1, pp. 77S-86S, 1996.

[31] LI. T. Chen, J. A. Y. Lee, B. S. Y. Chua, and T. S. Howe, "Hip fractures in the elderly: the impact of comorbid illnesses on hospitalisation costs," Annals of the Academy of Medicine Singapore, vol. 36, no. 9, pp. 784-787, 2007.

[32] S. Holmberg and K. G. Thorngren, "Consumption of hospital resources for femoral neck fracture," Acta Orthopaedica Scandinavica, vol. 59, no. 4, pp. 377-381, 1988.

[33] C. W. Davison, M. J. Merrilees, T. J. Wilkinson, J. S. McKie, R. Sainsbury, and N. L. Gilchrist, "Hip fracture mortality and morbidity—can we do better?" New Zealand Medical Journal, vol. 114, no. 1136, pp. 329-332, 2001. 
[34] A. H. Myers, E. G. Robinson, M. L. Van Natta, J. D. Michelson, K. Collins, and S. P. Baker, "Hip fractures among the elderly: factors associated with in-hospital mortality," American Journal of Epidemiology, vol. 134, no. 10, pp. 11281137, 1991.

[35] P. J. Meunier, "Epidemiology and prevention of hip fractures," in Proceedings of theILAR Congress of Rheumatology, vol. 19, pp. 65-68, Singapore, 1997.

[36] G. P. Lyritis, G. Dilsen, C. Gennari et al., "Epidemiology of hip fracture: the MEDOS study," Osteoporosis International, vol. 6, supplement 3, pp. S11-S15, 1996.

[37] S. Kitamura, Y. Hasegawa, S. Suzuki et al., "Functional outcome after hip fracture in Japan," Clinical Orthopaedics and Related Research, no. 348, pp. 29-36, 1998.

[38] Z. Arinzon, Z. Fidelman, A. Zuta, A. Peisakh, and Y. N. Berner, "Functional recovery after hip fracture in old-old elderly patients," Archives of Gerontology and Geriatrics, vol. 40, no. 3, pp. 327-336, 2005.

[39] A. L. Armstrong and W. A. Wallace, "The epidemiology of hip fractures and methods of prevention," Acta Orthopaedica Belgica, vol. 60, supplement 1, pp. 85-101, 1994.

[40] R. G. Cumming, R. Klineberg, and A. Katelaris, "Cohort study of risk of institutionalisation after hip fracture," Australian and New Zealand Journal of Public Health, vol. 20, no. 6, pp. 579-582, 1996.

[41] K. E. Dretakis, E. K. Dretakis, E. F. Papakitsou, S. Psarakis, and K. Steriopoulos, "Possible predisposing factors for the second hip fracture," Calcified Tissue International, vol. 62, no. 4, pp. 366-369, 1998.

[42] T. Dolk, "Influence of treatment factors on the outcome after hip fractures," Upsala Journal of Medical Sciences, vol. 94, no. 2, pp. 209-221, 1989.

[43] H. M. Schroder, K. K. Petersen, and M. Erlandsen, "Occurrence and incidence of the second hip fracture," Clinical Orthopaedics and Related Research, vol. 289, pp. 166-169, 1993.

[44] A. Yamanashi, K. Yamazaki, M. Kanamori et al., "Assessment of risk factors for second hip fractures in Japanese elderly," Osteoporosis International, vol. 16, no. 10, pp. 1239-1246, 2005.

[45] T. Nymark, J. M. Lauritsen, O. Ovesen, N. D. Röck, and B. Jeune, "Short time-frame from first to second hip fracture in the Funen County Hip Fracture Study," Osteoporosis International, vol. 17, no. 9, pp. 1353-1357, 2006.

[46] E. Lönnroos, H. Kautiainen, P. Karppi, S. Hartikainen, I. Kiviranta, and R. Sulkava, "Incidence of second hip fractures. A population-based study," Osteoporosis International, vol. 18, no. 9, pp. 1279-1285, 2007.

[47] S. D. Berry, E. J. Samelson, M. T. Hannan et al., "Second hip fracture in older men and women: the framingham study," Archives of Internal Medicine, vol. 167, no. 18, pp. 1971-1976, 2007.

[48] R. Marks, "Leg strength and hip fracture morbidityresults of 4 separate case studies," Journal of Musculoskeletal Research, vol. 9, no. 4, pp. 183-194, 2005.

[49] P. Lips, D. Karpf, E. Seeman et al., "Epidemiology and predictors of fractures associated with osteoporosis," American Journal of Medicine, vol. 103, pp. 3S-5S, 1997.

[50] S. Boonen, P. Broos, and J. Dequeker, "Age-related factors in the pathogenesis of senile (type II) femoral neck fractures: an integrated view," American Journal of Orthopedics, vol. 25, no. 3, pp. 198-204, 1996.
[51] L. A. Ahmed, H. Schirmer, A. Bjørnerem et al., "The genderand age-specific 10-year and lifetime absolute fracture risk in Tromsø, Norway," European Journal of Epidemiology, vol. 24, no. 8, pp. 441-448, 2009.

[52] J. Fielden, G. Purdie, G. Horne, and P. Devane, "Hip fracture incidence in New Zealand, revisited," New Zealand Medical Journal, vol. 114, no. 1129, pp. 154-156, 2001.

[53] O. Löfman, K. Berglund, L. Larsson, and G. Toss, "Changes in hip fracture epidemiology: redistribution between ages, genders and fracture types," Osteoporosis International, vol. 13, no. 1, pp. 18-25, 2002.

[54] S. Lim, BO. K. Koo, E. J. Lee et al., "Incidence of hip fractures in Korea," Journal of Bone and Mineral Metabolism, vol. 26, no. 4, pp. 400-405, 2008.

[55] G. P. Lyritis, G. Dilsen, C. Gennari et al., "Epidemiology of hip fracture: the MEDOS study," Osteoporosis International, vol. 6, supplement 3, pp. S11-S15, 1996.

[56] J. B. Lauritzen, "Hip fractures. Epidemiology, risk factors, falls, energy absorption, hip protectors, and prevention," Danish Medical Bulletin, vol. 44, no. 2, pp. 155-168, 1997.

[57] J. A. Baron, M. Karagas, J. Barrett et al., "Basic epidemiology of fractures of the upper and lower limb among americans over 65 years of age," Epidemiology, vol. 7, no. 6, pp. 612-618, 1996.

[58] L. J. Melton, "Epidemiology of hip fractures: implications of the exponential increase with age," Bone, vol. 18, pp. 121S125S, 1996.

[59] J. D. Zuckerman, "Hip fracture," The New England Journal of Medicine, vol. 334, pp. 1519-1525, 1996.

[60] D. S. Lauderdale, S. J. Jacobsen, S. E. Furner, P. S. Levy, J. A. Brody, and J. Goldberg, "Hip fracture incidence among elderly Asian-American populations," American Journal of Epidemiology, vol. 15, no. 6, pp. 502-509, 1997.

[61] L. K. H. Koh, S. M. Saw, J. J. M. Lee, K. H. Leong, and J. Lee, "Hip fracture incidence rates in Singapore 1991-1998," Osteoporosis International, vol. 12, no. 4, pp. 311-318, 2001.

[62] A. Memon, W. M. Pospula, A. Y. Tantawy, S. Abdul-Ghafai, A. Suresh, and A. Al-Rowaih, "Incidence of hip fracture in Kuwait," International Journal of Epidemiology, vol. 27, no. 5, pp. 860-865, 1998.

[63] V. Finsen, L. G. Johnsen, G. Tranø, B. Hansen, and K. S. Sneve, "Hip fracture incidence in central norway: a followup study," Clinical Orthopaedics and Related Research, no. 419, pp. 173-178, 2004.

[64] E. Czerwinski, J. A. Kanis, B. Trybulec, H. Johansson, P. Borowy, and J. Osieleniec, "The incidence and risk of hip fracture in Poland," Osteoporosis International, vol. 20, no. 8, pp. 1363-1367, 2009.

[65] S. J. Birge, "Osteoporosis and hip fracture," Clinics in Geriatric Medicine, vol. 9, no. 1, pp. 69-86, 1993.

[66] S. Boonen, J. Dequeker, and W. Pelemans, "Risk factors for falls as a cause of hip fracture in the elderly," Acta Clinica Belgica, vol. 48, no. 3, pp. 190-194, 1993.

[67] M. C. Nevitt, S. R. Cummings, S. Kidd, and D. Black, "Risk factors for recurrent nonsyncopal falls. A prospective study," Journal of the American Medical Association, vol. 261, no. 18, pp. 2663-2668, 1989.

[68] Z. Guo, P. Wills, M. Viitanen, J. Fastbom, and B. Winblad, "Cognitive impairment, drug use, and the risk of hip fracture in persons over 75 years old: a community-based prospective study," American Journal of Epidemiology, vol. 148, no. 9, pp. 887-892, 1998. 
[69] Y. Hasegawa, S. Suzuki, and H. Wingstrand, "Risk of mortality following hip fracture in Japan," Journal of Orthopaedic Science, vol. 12, no. 2, pp. 113-117, 2007.

[70] F. Formiga, A. Lopez-Soto, E. Duaso et al., "Characteristics of fall-related hip fractures in community-dwelling elderly patients according to cognitive status," Aging, vol. 20, no. 5, pp. 434-438, 2008.

[71] L. Feng, S. C. Scherer, B. Y. Tan, G. Chan, N. P. Fong, and T. P. Ng, "Comorbid cognitive impairment and depression is a significant predictor of poor outcomes in hip fracture rehabilitation," International Psychogeriatrics, vol. 22, no. 2, pp. 246-253, 2010.

[72] E. S. F. Coutinho, A. Fletcher, K. V. Bloch, and L. C. Rodrigues, "Risk factors for falls with severe fracture in elderly people living in a middle-income country: a case control study," BMC Geriatrics, vol. 8, article 21, 2008.

[73] A. Alfaro-Acha, G. V. Ostir, K. S. Markides, and K. J. Ottenbacher, "Cognitive status, body mass index, and hip fracture in older hispanic adults," Journal of the American Geriatrics Society, vol. 54, no. 8, pp. 1251-1255, 2006.

[74] R. Q. Ivers, R. Norton, R. G. Cumming, M. Butler, and A. J. Campbell, "Visual impairment and risk of hip fracture," American Journal of Epidemiology, vol. 152, no. 7, pp. 633639,2000

[75] A. K. Pfister, J. Mcjunkin, and D. A. Santrock, "Hip fracture outcomes and their prevention in Kanawha County, West Virginia," The West Virginia Medical Journal, vol. 95, no. 4, pp. 170-174, 1999.

[76] M. J. Lichtenstein, M. R. Griffin, J. E. Cornell, E. Malcolm, and W. A. Ray, "Risk factors for hip fractures occurring in the hospital," American Journal of Epidemiology, vol. 140, no. 9, pp. 830-838, 1994.

[77] J. M. Mossey, E. Mutran, K. Knott, and R. Craik, "Determinants of recovery 12 months after hip fracture: the importance of psychosocial factors," American Journal of Public Health, vol. 79, no. 3, pp. 279-286, 1989.

[78] M. E. Mussolino, "Depression and hip fracture risk: the NHANES I epidemiologic follow-up study," Public Health Reports, vol. 120, no. 1, pp. 71-75, 2005.

[79] R. Newson and E. Kemps, "The influence of physical and cognitive activities on simple and complex cognitive tasks in older adults," Experimental Aging Research, vol. 32, no. 3, pp. 341-362, 2006.

[80] M. W. Cree, "Hip fracture-related changes in health ratings of older patients with cognitive impairment," Aging and Mental Health, vol. 8, no. 6, pp. 524-529, 2004.

[81] O. Johnell, J. A. Kanis, A. Oden et al., "Predictive value of BMD for hip and other fractures," Journal of Bone and Mineral Research, vol. 20, no. 7, pp. 1185-1194, 2005.

[82] C. A. C. Wickham, K. Walsh, C. Cooper et al., "Dietary calcium, physical activity, and risk of hip fracture: a prospective study," British Medical Journal, vol. 299, no. 6704, pp. 889892, 1989.

[83] C. Cooper, D. J. P. Barker, and C. Wickham, "Physical activity, muscle strength, and calcium intake in fracture of the proximal femur in Britain," British Medical Journal, vol. 297, no. 6661, pp. 1443-1446, 1988.

[84] S. R. Cummings, M. C. Nevitt, W. S. Browner et al., "Risk factors for hip fracture in white women," New England Journal of Medicine, vol. 332, no. 12, pp. 814-815, 1995.

[85] M. E. Farmer, T. Harris, J. H. Madans, R. B. Wallace, J. Cornoni-Huntley, and L. R. White, "Anthropometric indicators and hip fracture. The NHANES I epidemiologic follow-up study," Journal of the American Geriatrics Society, vol. 37, no. 1, pp. 9-16, 1989.

[86] T. S. Wei, C. H. Hu, S. H. Wang, and K. L. Hwang Departments of, "Fall characterictics, functional mobility and bone mineral density as risk factors of hip fracture in the community-dwelling ambulatory elderly," Osteoporosis International, vol. 12, no. 12, pp. 1050-1055, 2001.

[87] K. M. Fox, S. R. Cummings, E. Williams, and K. Stone, "Femoral neck and intertrochanteric fractures have different risk factors: a prospective study," Osteoporosis International, vol. 11, no. 12, pp. 1018-1023, 2000.

[88] P. Fitzpatrick, P. N. Kirke, L. Daly et al., "Predictors of first hip fracture and mortality post fracture in older women," Irish Journal of Medical Science, vol. 170, no. 1, pp. 49-53, 2001.

[89] S. R. Cummings, J. L. Kelsey, M. C. Nevitt, and K. J. O'Dowd, "Epidemiology of osteoporosis and osteoporotic fractures," Epidemiologic Reviews, vol. 7, pp. 178-208, 1985.

[90] S. R. Cummings and M. C. Nevitt, "A hypothesis: the causes of hip fractures," Journals of Gerontology, vol. 44, no. 4, pp. M107-M111, 1989.

[91] R. Norton, G. Galgali, A. John Campbell et al., "Is physical activity protective against hip fracture in frail older people?" Age and Ageing, vol. 30, no. 3, pp. 262-264, 2001.

[92] N. D. Nguyen, C. Pongchaiyakul, J. R. Center, J. A. Eisman, and T. V. Nguyen, "Identification of high-risk individuals for hip fracture: a 14-year prospective study," Journal of Bone and Mineral Research, vol. 20, no. 11, pp. 1921-1928, 2005.

[93] C. Slemenda, S. Cummings, E. Seeman, P. Lips, D. Black, and D. B. Karpf, "Prevention of hip fractures: risk factor modification," American Journal of Medicine, vol. 103, pp. 65S-73S, 1997.

[94] P. Dargent-Molina, A. M. Schott, D. Hans et al., "Separate and combined value of bone mass and gait speed measurements in screening for hip fracture risk: results from the EPIDOS study," Osteoporosis International, vol. 9, no. 2, pp. 188-192, 1999.

[95] P. Stolee, J. Poss, R. J. Cook, K. Byrne, and J. P. Hirdes, "Risk factors for hip fracture in older home care clients," Journals of Gerontology-Series A Biological Sciences and Medical Sciences, vol. 64, no. 3, pp. 403-410, 2009.

[96] T. Lang, J. A. Cauley, F. Tylavsky, D. Bauer, S. Cummings, and T. B. Harris, "Computed tomographic measurements of thigh muscle cross-sectional area and attenuation coefficient predict hip fracture: the health, aging, and body composition study," Journal of Bone and Mineral Research, vol. 25, no. 3, pp. 513-519, 2010.

[97] R. G. Cumming and R. J. Klineberg, "Fall frequency and characteristics and the risk of hip fractures," Journal of the American Geriatrics Society, vol. 42, no. 7, pp. 774-778, 1994.

[98] H. Jokinen, P. Pulkkinen, J. Korpelainen et al., "Risk factors for cervical and trochanteric hip fractures in elderly women: a population-based 10-year follow-up study," Calcified Tissue International, vol. 87, no. 1, pp. 44-51, 2010.

[99] A. Moayyeri, "The association between physical activity and osteoporotic fractures: a review of the evidence and implications for future research," Annals of Epidemiology, vol. 18, no. 11, pp. 827-835, 2008.

[100] S. Sihvonen, J. Kulmala, M. Kallinen, M. Alén, I. Kiviranta, and S. Sipilä, "Postural balance and self-reported balance confidence in older adults with a hip fracture history," Gerontology, vol. 55, no. 6, pp. 630-636, 2009. 
[101] S. Rojanasthien and S. Luevitoonvechkij, "Epidemiology of hip fracture in Chiang Mai," Journal of the Medical Association of Thailand, vol. 88, supplement 5, pp. S105-109, 2005.

[102] A. H. Holmberg, O. Johnell, P. M. Nilsson, J. Å. Nilsson, G. Berglund, and K. Åkesson, "Risk factors for hip fractures in a middle-aged population: a study of 33,000 men and women," Osteoporosis International, vol. 16, no. 12, pp. 2185-2194, 2005.

[103] R. T. Wilson, G. A. Chase, E. A. Chrischilles, and R. B. Wallace, "Hip fracture risk among community-dwelling elderly people in the United States: a prospective study of physical, cognitive, and socioeconomic indicators," American Journal of Public Health, vol. 96, no. 7, pp. 1210-1218, 2006.

[104] B. Has, A. Nagy, E. Has-Schön, R. Pavić, J. Kristek, and B. Splavski, "Influence of instability and muscular weakness in ethiopathogenesis of hip fractures," Collegium Antropologicum, vol. 30, no. 4, pp. 823-827, 2006.

[105] BO. Abrahamsen, M. F. Nielsen, P. Eskildsen, J. T. Andersen, S. Walter, and K. Brixen, "Fracture risk in Danish men with prostate cancer: a nationwide register study," BJU International, vol. 100, no. 4, pp. 749-754, 2007.

[106] J. Kulmala, S. Sihvonen, M. Kallinen, M. Alen, I. Kiviranta, and S. Sipilä, "Balance confidence and functional balance in relation to falls in older persons with hip fracture history," Journal of Geriatric Physical Therapy, vol. 30, no. 3, pp. 114120, 2007.

[107] J. Robbins, A. K. Aragaki, C. Kooperberg et al., "Factors associated with 5-year risk of hip fracture in postmenopausal women," Journal of the American Medical Association, vol. 298, no. 20, pp. 2389-2398, 2007.

[108] A. C. Looker and M. E. Mussolino, "Serum 25hydroxyvitamin D and hip fracture risk in older U.S. white adults," Journal of Bone and Mineral Research, vol. 23, no. 1, pp. 143-150, 2008.

[109] D. F. Apple Jr. and W. C. Hayes, Prevention of Falls and Hip Fractures in the Elderly, American Academy of Orthopaedic Surgeons, Rosemont, Ill, USA, 1994.

[110] R. Sandler and S. Robinovitch, "An analysis of the effect of lower extremity strength on impact severity during a backward fall," Journal of Biomechanical Engineering, vol. 123, no. 6, pp. 590-598, 2001.

[111] A. H. Myers, Y. Young, and J. A. Langlois, "Prevention of falls in the elderly," Bone, vol. 18, no. 1, pp. 87S-101S, 1996.

[112] M. B. Sabick, J. G. Hay, V. K. Goel, and S. A. Banks, "Active responses decrease impact forces at the hip and shoulder in falls to the side," Journal of Biomechanics, vol. 32, no. 9, pp. 993-998, 1999.

[113] S. L. Greenspan, E. R. Myers, D. P. Kiel, R. A. Parker, W. C. Hayes, and N. M. Resnick, "Fall direction, bone mineral density, and function: risk factors for hip fracture in frail nursing home elderly," American Journal of Medicine, vol. 104, no. 6, pp. 539-545, 1998.

[114] B. E. Groen, E. Smulders, D. De Kam, J. Duysens, and V. Weerdesteyn, "Martial arts fall training to prevent hip fractures in the elderly," Osteoporosis International, vol. 21, no. 2, pp. 215-221, 2010.

[115] J. L. Baird and R. E.A. Van Emmerik, "Young and older adults use different strategies to perform a standing turning task," Clinical Biomechanics, vol. 24, no. 10, pp. 826-832, 2009.

[116] M. J. Parker, T. R. Twemlow, and G. A. Pryor, "Environmental hazards and hip fractures," Age and Ageing, vol. 25, no. 4, pp. 322-325, 1996.
[117] F. A. Sorond, A. Galica, J. M. Serrador et al., "Cerebrovascular hemodynamics, gait, and falls in an elderly population: MOBILIZE Boston Study," Neurology, vol. 74, no. 20, pp. 1627-1633, 2010.

[118] J. A. Grisso, J. L. Kelsey, B. L. Strom et al., "Risk factors for falls as a cause of hip fracture in women," New England Journal of Medicine, vol. 324, no. 19, pp. 1326-1331, 1991.

[119] T. Buckley, C. Pitsikoulis, E. Barthelemy, and C. J. Hass, "Age impairs sit-to-walk motor performance," Journal of Biomechanics, vol. 42, no. 14, pp. 2318-2322, 2009.

[120] K. Michaëlsson, H. Olofsson, K. Jensevik et al., "Leisure physical activity and the risk of fracture in men," PLoS Medicine, vol. 4, no. 6, article e199, 2007.

[121] P. Suriyawongpaisal, R. Rajatanavin, A. Takkinstien, S. Wanvarie, and P. Apiyasawat, "Physical activity and risk factors for hip fractures in Thai men," Southeast Asian Journal of Tropical Medicine and Public Health, vol. 32, no. 1, pp. 196-203, 2001.

[122] C. Coupland, D. Wood, and C. Cooper, "Physical inactivity is an independent risk factor for hip fracture in the elderly," Journal of Epidemiology and Community Health, vol. 47, no. 6, pp. 441-443, 1993.

[123] J. A. Grisso, J. L. Kelsey, L. A. O’Brien et al., "Risk factors for hip fracture in men," American Journal of Epidemiology, vol. 145, no. 9, pp. 786-793, 1997.

[124] E. W. Gregg, J. A. Cauley, D. G. Seeley, K. E. Ensrud, and D. C. Bauer, "Physical activity and osteoporotic fracture risk in older women," Annals of Internal Medicine, vol. 129, no. 2, pp. 81-88, 1998.

[125] J. Kanis, O. Johnell, B. Gullberg et al., "Risk factors for hip fracture in men from southern europe: the MEDOS study," Osteoporosis International, vol. 9, no. 1, pp. 45-54, 1999.

[126] U. M. Kujala, J. Kaprio, P. Kannus, S. Sarna, and M. Koskenvuo, "Physical activity and osteoporotic hip fracture risk in men," Archives of Internal Medicine, vol. 160, no. 5, pp. 705-708, 2000.

[127] B. Y. Farahmand, P.-G. Persson, K. Michaëlsson et al., "Physical activity and hip fracture: a population-based casecontrol study," International Journal of Epidemiology, vol. 29, no. 2, pp. 308-314, 2000.

[128] U. Englund, P. Nordström, J. Nilsson et al., "Physical activity in middle-aged women and hip fracture risk: the UFO study," Osteoporosis International, vol. 22, no. 2, pp. 499-505, 2010.

[129] S. Høidrup, T. I .A. Sørensen, U. Strøger, J. B. Lauritzen, M. Schroll, and M. Grønbæk, "Leisure-time physical activity levels and changes in relation to risk of hip fracture in men and women," American Journal of Epidemiology, vol. 154, no. 1, pp. 60-68, 2001.

[130] A. Devine, S. S. Dhaliwal, I. M. Dick, J. Bollerslev, and R. L. Prince, "Physical activity and calcium consumption are important determinants of lower limb bone mass in older women," Journal of Bone and Mineral Research, vol. 19, no. 10, pp. 1634-1639, 2004.

[131] D. Feskanich, W. Willett, and G. Colditz, "Walking and leisure-time activity and risk of hip fracture in postmenopausal women," Journal of the American Medical Association, vol. 288, no. 18, pp. 2300-2306, 2002.

[132] S. Morita, T. Jinno, H. Nakamura, Y. Kumei, K. Shinomiya, and $\mathrm{H}$. Yamamoto, "Bone mineral density and walking ability of elderly patients with hip fracture: a strategy for prevention of hip fracture," Injury, vol. 36, no. 9, pp. 1075-1079, 2005.

[133] P. M. Cawthon, R. L. Fullman, L. Marshall et al., "Physical performance and risk of hip fractures in older men," Journal of Bone and Mineral Research, vol. 23, no. 7, pp. 1037-1044, 2008. 
[134] P. Trimpou, K. Landin-Wilhelmsen, A. Odén, A. Rosengren, and L. Wilhelmsen, "Male risk factors for hip fracturea 30-year follow-up study in 7,495 men," Osteoporosis International, vol. 21, no. 3, pp. 409-416, 2010.

[135] N. Bean, K. M. Bennett, and A. B. Lehmann, "Habitus and hip fracture revisited: skeletal size, strength and cognition rather than thinness?" Age and Ageing, vol. 24, no. 6, pp. 481484, 1995.

[136] C. M. Nielson, M. L. Bouxsein, S. S. Freitas, K. E. Ensrud, and E. S. Orwoll, "Trochanteric soft tissue thickness and hip fracture in older men," Journal of Clinical Endocrinology and Metabolism, vol. 94, no. 2, pp. 491-496, 2009.

[137] S. R. Lord, J. A. Ward, P. Williams, and K. J. Anstey, "Physiological factors associated with falls in older communitydwelling women," Journal of the American Geriatrics Society, vol. 42, no. 10, pp. 1110-1117, 1994.

[138] M. J. Parker and C. R. Palmer, "Prediction of rehabilitation after hip fracture," Age and Ageing, vol. 24, no. 2, pp. 96-98, 1995.

[139] A. H. Myers, M. H. Palmer, B. T. Engel, D. J. Warrenfeltz, and J. A. Parker, "Mobility in older patients with hip fractures: examining prefracture status, complications, and outcomes at discharge from the acute-care hospital," Journal of Orthopaedic Trauma, vol. 10, no. 2, pp. 99-107, 1996.

[140] J. D. Barangan, "Factors that influence recovery from hip fracture during hospitalization," Orthopaedic nursing / National Association of Orthopaedic Nurses, vol. 9, no. 5, pp. 19-30, 1990.

[141] L. Ceder, K. Svensson, and K. G. Thorngren, "Statistical prediction of rehabilitation in elderly patients with hip fractures," Clinical Orthopaedics and Related Research, vol. 152, pp. 185-190, 1980.

[142] K. M. Fox, W. G. Hawkes, J. R. Hebel et al., "Mobility after hip fracture predicts health outcomes," Journal of the American Geriatrics Society, vol. 46, no. 2, pp. 169-173, 1998.

[143] J. A. Langlois, M. Visser, L. S. Davidovic, S. Maggi, G. Li, and T. B. Harris, "Hip fracture risk in older white men is associated with change in body weight from age 50 years to old age," Archives of Internal Medicine, vol. 158, no. 9, pp. 990-996, 1998.

[144] C. De Laet, J. A. Kanis, A. Odén et al., "Body mass index as a predictor of fracture risk: a meta-analysis," Osteoporosis International, vol. 16, no. 11, pp. 1330-1338, 2005.

[145] N. Maffulli, T. W. Dougall, M. T. F. Brown, and M. H. N. Golden, "Nutritional differences in patients with proximal femoral fractures," Age and Ageing, vol. 28, no. 5, pp. 458462, 1999.

[146] E. K. Dretakis and N. A. Christodoulou, "Significance of endogenic factors in the location of fractures of the proximal femur," Acta Orthopaedica Scandinavica, vol. 54, no. 2, pp. 198-203, 1983.

[147] P. Skałba, A. Korfanty, W. Mroczka, and M. Wójtowicz, "Changes of SHBG concentrations in postmenopausal womenZmiany stezeń SHBG we krwi wystepujace u kobiet po menopauzie," Ginekologia Polska, vol. 72, no. 12 A, pp. 1388-1392, 2001.

[148] O. Johnell, L. J. Melton III, E. J. Atkinson, W. M. O’Fallon, and L. T. Kurland, "Fracture risk in patients with Parkinsonism: a population-based study in Olmsted County, Minnesota," Age and Ageing, vol. 21, no. 1, pp. 32-38, 1992.

[149] D. M. Buchner and E. B. Larson, "Falls and fractures in patients with Alzheimer-type dementia," Journal of the American Medical Association, vol. 257, no. 11, pp. 14921495, 1987.
[150] L. Christodoulou Ath. L. and E. K. Dretakis, "Significance of muscular disturbances in the localization of fractures of the proximal femur," Clinical Orthopaedics and Related Research, vol. 187, pp. 215-217, 1984.

[151] A. V. Schwartz, D. E. Sellmeyer, K. E. Ensrud et al., "Older women with diabetes have an increased risk of fracture: a prospective study," Journal of Clinical Endocrinology and Metabolism, vol. 86, no. 1, pp. 32-38, 2001.

[152] S. Boonen, P. Broos, and P. Haentjens, "Factors associated with hip fracture occurrence in old age. Implications in the postsurgical management," Acta Chirurgica Belgica, vol. 99, no. 4, pp. 185-189, 1999.

[153] G. Poor, E. J. Atkinson, W. M. O’Fallon, and L. J. Melton III, "Predictors of hip fractures in elderly men," Journal of Bone and Mineral Research, vol. 10, no. 12, pp. 1900-1907, 1995.

[154] J. A. Grisso, J. L. Kelsey, B. L. Strom et al., "Risk factors for hip fracture in black women," New England Journal of Medicine, vol. 330, no. 22, pp. 1555-1559, 1994.

[155] D. D. French, E. Bass, D. D. Bradham, R. R. Campbell, and L. Z. Rubenstein, "Rehospitalization after hip fracture: predictors and prognosis from a national veterans study," Journal of the American Geriatrics Society, vol. 56, no. 4, pp. 705-710, 2008.

[156] J. J.W. Roche, R. T. Wenn, O. Sahota, and C. G. Moran, "Effect of comorbidities and postoperative complications on mortality after hip fracture in elderly people: prospective observational cohort study," British Medical Journal, vol. 331, no. 7529, pp. 1374-1376, 2005.

[157] J.-P. Kaukonen, P. Lüthje, I. Nurmi-Lüthje, M. Kataja, and H. Naboulsi, "Second hip fracture and patients' medication after the first hip fracture: a follow-up of 221 hip fracture patients in Finland," Archives of Gerontology and Geriatrics, vol. 52, no. 2, pp. 185-189, 2011.

[158] R. Norton, A. J. Campbell, T. Lee-Joe, E. Robinson, and M. Butler, "Circumstances of falls resulting in hip fractures among older people," Journal of the American Geriatrics Society, vol. 45, no. 9, pp. 1108-1112, 1997.

[159] M. B. King and M. E. Tinetti, "A multifactorial approach to reducing injurious falls," Clinics in Geriatric Medicine, vol. 12, no. 4, pp. 745-759, 1996.

[160] E. Allander, B. Gullberg, O. Johnell et al., "Circumstances around the fall in a multinational hip fracture risk study: a diverse pattern for prevention," Accident Analysis and Prevention, vol. 30, no. 5, pp. 607-616, 1998.

[161] S. Giaquinto, I. Majolo, E. Palma, S. Roncacci, A. Sciarra, and E. Vittoria, "Very old people can have favorable outcome after hip fracture: 58 patients referred to rehabilitation," Archives of Gerontology and Geriatrics, vol. 31, no. 1, pp. 13-18, 2000.

[162] D. Maggio, E. Ubaldi, G. Simonelli, S. Cenci, C. Pedone, and A. Cherubini, "Hip fracture in nursing homes: an Italian study on prevalence, latency, risk factors, and impact on mobility," Calcified Tissue International, vol. 68, no. 6, pp. 337-341, 2001.

[163] R. Van Balen, E. W. Steyerberg, J. J. Polder, T. L. M. Ribbers, J. D. F. Habbema, and H. J. M. Cools, "Hip fracture in elderly patients: outcomes for function, quality of life, and type of residence," Clinical Orthopaedics and Related Research, vol. 390, pp. 232-243, 2001.

[164] P. Kirke, M. Sutton, H. Burke, and L. Daly, "Outcome of hip fracture in older Irish women: a 2-year follow-up of subjects in a case-control study," Injury, vol. 1654, pp. 1-5, 2002.

[165] M. K. Karlsson, A. Nordqvist, and C. Karlsson, "Physical activity, muscle function, falls andfractures," Food \& Nutrition Research, vol. 52, 2008. 
[166] J.-P. Empana, P. Dargent-Molina, and G. Bréart, "Effect of hip fracture on mortality in elderly women: the EPIDOS prospective study," Journal of the American Geriatrics Society, vol. 52, no. 5, pp. 685-690, 2004.

[167] P. Haentjens, J. Magaziner, C. S. Colón-Emeric et al., "Metaanalysis: excess mortality after hip fracture among older women and men," Annals of Internal Medicine, vol. 152, no. 6, pp. 380-390, 2010.

[168] V. Juliebø, M. Krogseth, E. Skovlund, K. Engedal, and T. B. Wyller, "Medical treatment predicts mortality after hip fracture," Journals of Gerontology-Series A Biological Sciences and Medical Sciences, vol. 65 A, no. 4, pp. 442-449, 2010.

[169] C.-A. Ho, C.-Y. Li, K.-S. Hsieh, and H.-F. Chen, "Factors determining the 1-year survival after operated hip fracture: a hospital-based analysis," Journal of Orthopaedic Science, vol. 15, no. 1, pp. 30-37, 2010.

[170] U. Bergström, H. Jonsson, Y. Gustafson, U. Pettersson, H. Stenlund, and O. Svensson, "The hip fracture incidence curve is shifting to the right: a forecast of the age-quake," Acta Orthopaedica, vol. 80, no. 5, pp. 520-524, 2009.

[171] H. Arakaki, I. Owan, H. Kudoh et al., "Epidemiology of hip fractures in Okinawa, Japan," Journal of Bone and Mineral Metabolism. In press.

[172] C. J. Caspersen, K. E. Powell, and G. Christenson, "Physical activity, exercise and physical fitness: definitions and distinctions for health-related research," Public Health Reports, vol. 100, no. 2, pp. 125-131, 1985.

[173] A. Salpakoski, E. Portegijs, M. Kallinen et al., "Physical inactivity and pain in older men and women with hip fracture history," Gerontology, vol. 57, no. 1, 2011.

[174] M. Karlsson, J. Å. Nilsson, I. Sernbo, I. Redlund-Johnell, O. Johnell, and K. J. Obrant, "Changes of bone mineral mass and soft tissue composition after hip fracture," Bone, vol. 18, no. 1, pp. 19-22, 1996.

[175] P. N. Kannegaard, S. van der Mark, P. Eiken, and B. O. Abrahamsen, "Excess mortality in men compared with women following a hip fracture. National analysis of comedications, comorbidity and survival," Age and Ageing, vol. 39, no. 2, pp. 203-209, 2010.

[176] L. J. Melton and S. R. Cummings, "Heterogeneity of agerelated fractures: implications for epidemiology," Bone and Mineral, vol. 2, no. 4, pp. 321-331, 1987.

[177] S. R. Cummings and M. C. Nevitt, "Non-skeletal determinants of fractures: the potential importance of the mechanics of falls," Osteoporosis International, vol. 4, supplement 1, pp. S67-S70, 1994.

[178] R. M. Joakimsen, J. H. Magnus, and V. Fønnebø, "Physical activity and predisposition for hip fractures: a review," Osteoporosis International, vol. 7, no. 6, pp. 503-513, 1997.

[179] L. D. Gillespie, M. C. Robertson, W. J. Gillespie et al., "Interventions for preventing falls in older people living in the community," Cochrane Database of Systematic Reviews, vol. 15, no. 2, Article ID CD007146, 2009.

[180] M. Runge and E. Schacht, "Proximal femoral fractures in the elderly: pathogenesis, sequelae, interventions," Rehabilitation, vol. 38, no. 3, pp. 160-169, 1999. 


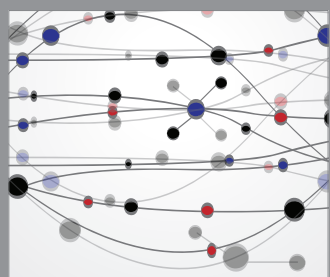

The Scientific World Journal
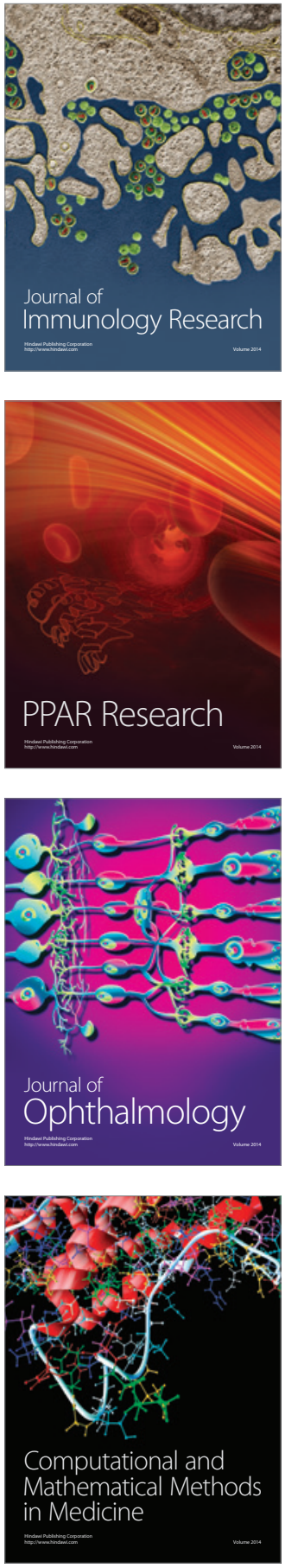

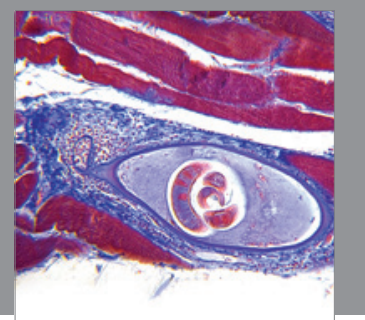

Gastroenterology

Research and Practice
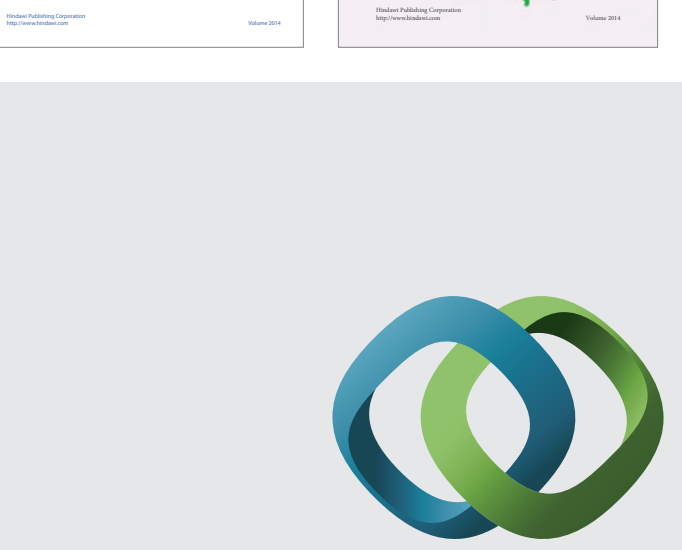

\section{Hindawi}

Submit your manuscripts at

http://www.hindawi.com
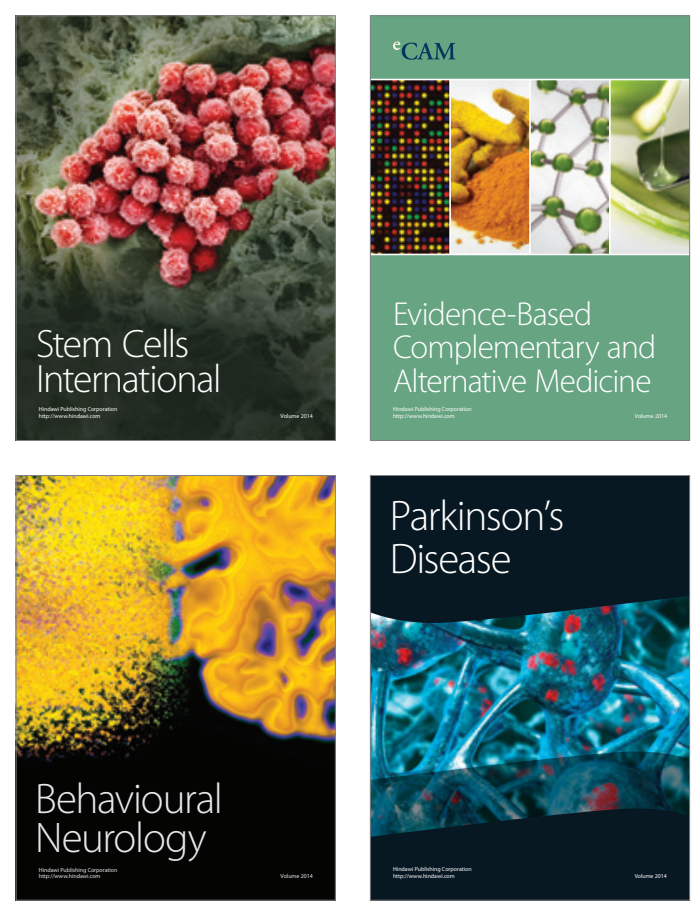

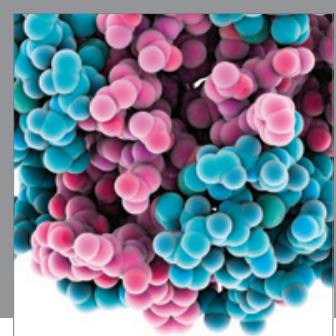

Journal of
Diabetes Research

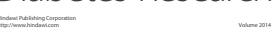

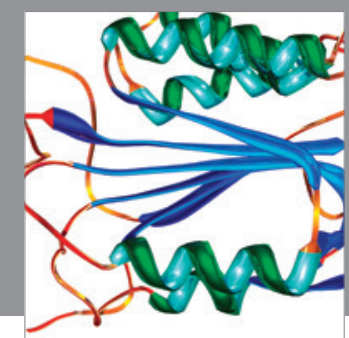

Disease Markers
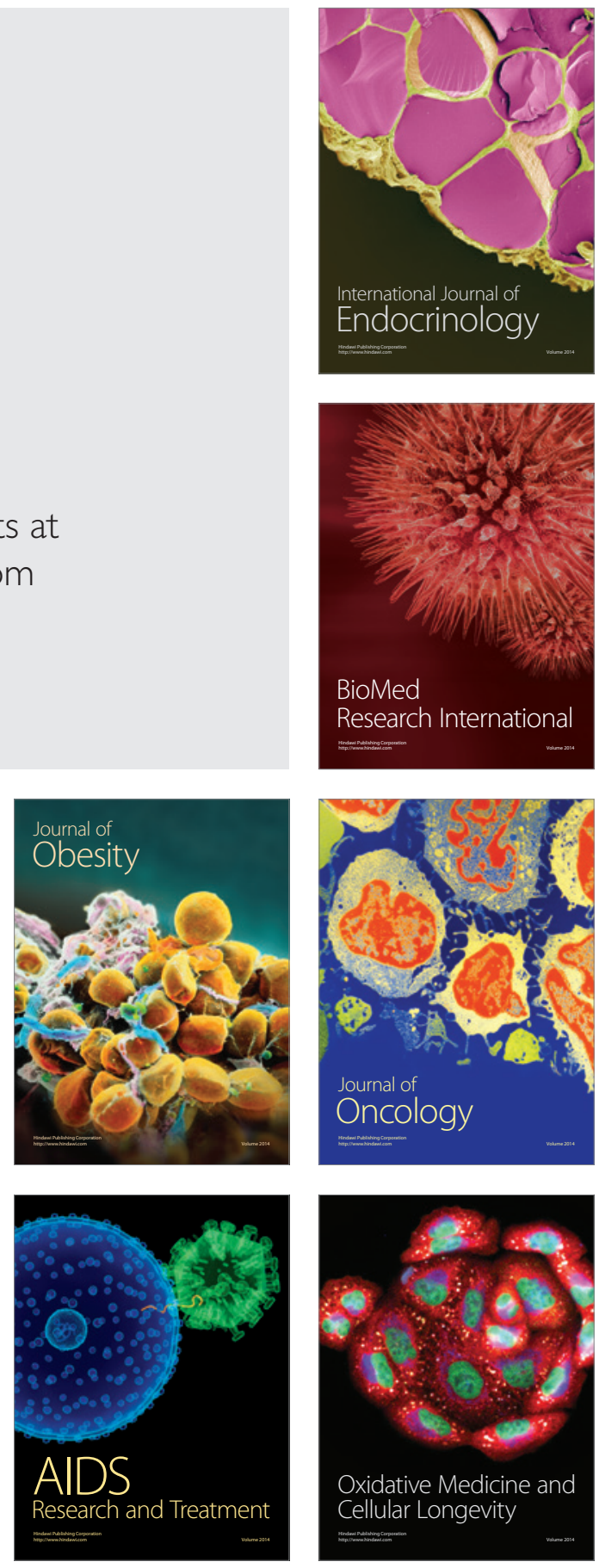